\title{
Evaluation of Genetic Stability in Olive Callus- induced and Meristem-induced Shoots using Flow Cytometry and Amplified Fragment Length Polymorphism Techniques
}

\section{Leila Mirzaei}

Tarbiat Modares University Faculty of Agriculture

Abbas Yadollahi ( $\sim$ yadollah@modares.ac.ir)

University of Tarbiat Modares, Tehran https://orcid.org/0000-0003-1889-9571

Maryam Jafarkhani Kermani

ABRII: Agricultural Biotechnology Research Institute of Iran

Masoud Naderpour

SPCRI: Seed and Plant Certification Research Institute

\section{Ali Asghar Zeinanloo}

AREEO: Agricultural Research Education and Extension Organization

\section{Maryam Farsi}

ABRII: Agricultural Biotechnology Research Institute of Iran

\section{Dariush Davoodi}

ABRII: Agricultural Biotechnology Research Institute of Iran

\section{Research}

Keywords: Genetic stability, AFLP, Periodical mini bioreactor, Light intensity, Carbon source, Olive (Olea europaea L.)

Posted Date: November 25th, 2020

DOI: https://doi.org/10.21203/rs.3.rs-112903/v1

License: (c) (i) This work is licensed under a Creative Commons Attribution 4.0 International License. Read Full License

Version of Record: A version of this preprint was published at Plant Methods on March 29th, 2021. See the published version at https://doi.org/10.1186/s13007-021-00724-7. 


\section{Abstract}

\section{Background}

In vitro culture of olive, as an economically valuable tree, has fundamentally genotype-dependant low micropropagation rate which need to be improved in already established cultivars, while needing to be struggled in firstly considered cultivars. Various plant tissue culture media, planting systems and growth factors were evaluated in two promissing Iranian olive cultivars $₫ A m i n \bigotimes$ and $₫$ Meshkat $\Downarrow$ plus a

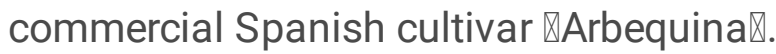

Results

The results showed that in $₫$ Amin $₫$ cultivar MS enriched with zeatin $(4 \mathrm{mg} / \mathrm{L})$, in $₫$ Arbequina $\$ cultivar OM enriched with zeatin $(1 \mathrm{mg} / \mathrm{L})$ and in $\triangle$ Meshkat $\triangle$ cultivar OM and MS enriched with zeatin $(2 \mathrm{mg} / \mathrm{L})$ produced reasonably healthier in vitro plantlets. The results indicated that using Periodical Mini Bioreactor (PMB) system in the presence of VS medium in $\triangle A m i n \rrbracket$ cultivar resulted in growth indicies amelioration compared to semi-solid media. Regarding carbon sources and light intensities, mannitol and

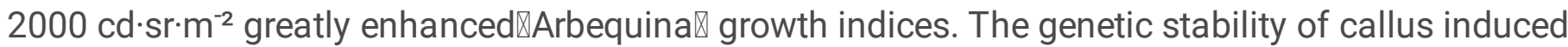
shoots (CIS) was compared with meristem induced shoots (MIS) using Amplified Fragment Length Polymorphism (AFLP) marker and flow cytometery (FCM). The results revealed that $2 \mathrm{C}$ DNA value assessed by partec FCM was mostly depended on the cultivars rather than the origin of generation -callus or meristem-. The AFLP results also showed that the cultivars were classified regardless of the micropropagation origin (CIS or MIS), except for $₫$ Arbequina $\bigotimes$. However, $₫$ Arbequina $₫ \mathrm{CIS}$ and MIS still had $62-80 \%$ of genetic similarity with three other categories and the highest resemblance (97\%) was seen with MIS of $₫$ Amin $₫$ cultivar.

\section{Conclusions}

Briefly,olive in vitro propagation optimization co-produced large volume and percent of calli resulting in more undesired indirect organogenesis. True to typeness of CIS was assessed showing that no changes in DNA amount occurred. Nonetheless, in phylogenetic analysis cultivars were clustered separately even

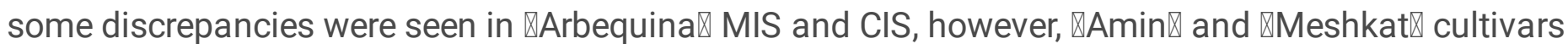
were more stable in clustering.

\section{Background}

Olive (Olea europaea L.) is the only edible species belongs to oleaceae family which was probably domesticated from subspecies sylvestris (López-Escudero and Mercado-Blanco, 2011), and it is amongst the earliest fruit trees in the Middle East (Bandelj et al., 2004). The first olive was cultivated in Asia before 1000 B.C. (Zohary and Hopf, 1994). The genus Olea has 30 species all around the world (Rugini and Caricato, 1995) and olive is an outcrossing, diploid species with vast genetic diversity (Bartolini et al., 
1998). Due to its multiple applications including oil, wood and fruit, olive is considered a valuable economic tree (Bandelj et al., 2004; Grati-Kamoun et al., 2006; Loureiro et al., 2007; Owen et al., 2005).

The in vitro culture of olive is restricted due to the limited sampling season (Sadder, 2002), tough cultivardependent proliferation (Rugini, 1984), slow lateral bud outgrowth (Benelli and De Carlo, 2018), mucus accumulation in the intercellular spaces called hyperhydricity (Grigoriadou et al., 2005), inhibitor phenolic compounds (Sadder, 2002), costly protocols (Benelli and De Carlo, 2018) and high losses of plantlets (Sadder, 2002).

Cultivar, media and PGR combinations are the most critical factors in olive proliferation (Ali et al., 2009; Rugini et al., 2016). The olive growth quality is highly affected by olive media (OM) (Moradnezhad et al., 2017; Rugini, 1984) and zeatin is the most well-known effective PGR in olive's shoot regeneration and

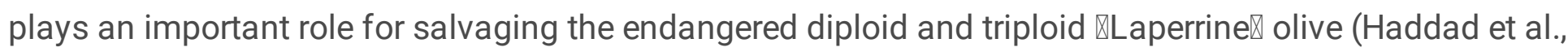
2018). Culture system also influences olive growth indices (Benelli and De Carlo, 2018; Grigoriadou et al., 2005; Rugini et al., 1997; Sadder, 2002). Some species are sensitive to be immersed in liquid continuously which may cause severe vitrification (Benelli and De Carlo, 2018). Temporary Immersion System (TIS) resolve such problematic issues in tropical crops and is promising for woody plants (Grigoriadou et al., 2005). It overcomes gas accumulation, reduces the mass production costs (Benelli and De Carlo, 2018) and causes the least hyperhydricity (Grigoriadou et al., 2005). Survival rates and plantlet quality in TIS is higher than normal solidified conditions. To economize plant production, zeatin can be reduced to $50 \%$ in

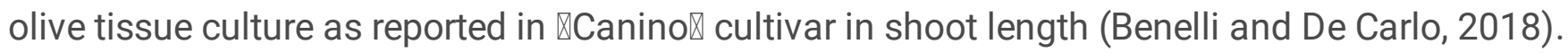

Mannitol, a sugar alcohol consisting of $30 \%$ of total carbohydrates in leaves and branches is the main photosynthesis product in olive (Bustan et al., 2011) and in combination with OM, influences shoots and node numbers per shoot significantly (Moradnezhad et al., 2017). It also uniforms olive's secondary axillary shoots (Leva et al., 2013). The application of mannitol for seven subcultures resulted in total survival in comparison with the application of sucrose with $54 \%$ survival (Leva et al., 2013). It is also reported that light type is a determinative environmental factor in olive growth (Moradnezhad et al., 2017).

Tissue culture of olive could encounter some physiological abnormalities such as callusing (Leva et al., 2013). OM normally causes callus in the bottom of petioles and basal part of plantlet, but some of the olive cultivars are only able to multiply on OM (Brito et al., 2010; Sadder, 2002). Callus formation mostly depends on cultivars, media and PGRs (Rugini, 1984; Sadder, 2002, Oulbi, Toufik, \& Belkoura, 2014). Since somaclonal variation is considered an approach to breed plants with the restricted genetic base, but elite genotypes selection necessitates fidelity during in vitro propagation. Therefore, genetic uniformity detection in in vitro-raised plants at an early stage is desirable (Krishna et al., 2016). In ploidy level

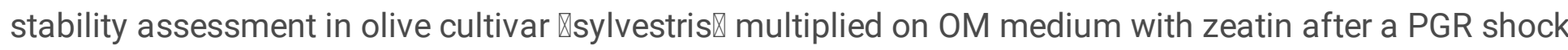
followed by transferring to the same medium without PGRs, the DNA content was reduced to 2.5 to $9 \%$ in the micropropagated plants (Brito et al., 2010). It is reported that intraclonal variations in quantitative traits of $\triangle$ Picual $\square$ architecture, which were prominently affected by genotype and continual period of in 
vitro culturing, occur in somatically propagated plantlets (Bradaï et al., 2016). Moreover, nuclear DNA content in highly reproducible histograms in olive species was significantly different between donor plants and acclimatized plants (Brito et al., 2010).

Molecular markers give the chance of early progenies stability check (De la Rosa et al., 2003). AFLP is a tedious and time-consuming method resulting in high reproducibility and efficiency for detecting polymorphism (Bandelj et al., 2004 and Grati-Kamoun et al., 2006). Because of high discriminating capacity of AFLP, it is a reliable method to investigate genetic diversity (Owen et al., 2005). AFLP is normally used for map construction due to the huge number of polymorphism and scorable loci (De la Rosa et al., 2003). For revealing numerous bands per reaction and valuable number of indices, AFLP is considered the most efficient marker for olive in comparison with SSR and RAPD (Belaj et al., 2003) because it is distributed homogeneously in olive linkage groups (De la Rosa et al., 2003; Owen et al., 2005). In addition, not only the efficiency index (number of loci, discriminating power and number of pattern per assay) was reported the most, but also the average confusion probability was the least (Belaj et al., 2003).

$\triangle A m i n \nabla$ and $\triangle$ Meshkat $\nabla(63 \%$ and $66 \%$ oil, 14 and $21 \mathrm{Kg} /$ tree yeild, repectively) are two commercial Iranian cultivars with both table and oil consumption which have similar specifications to the international commercial cultivars like $\llbracket$ Arbequina $\(65 \%$ oil and $25 \mathrm{Kg} /$ tree yeild in Iran) and so, their mass propagation optimization guaranteing ascertained genetic trueness is a serious demand. In this regard, different plant tissue culture media such as OM, MS and VS, planting systems including PMB and SSM and growth requirements like light intensity and carbon sources were investigated to abtain the most optimized olive propagation protocol.

\section{Results}

\section{Effects of zeatin and cultivar on growth indices at proliferation step}

MS containing $4 \mathrm{mg} / \mathrm{L}$ zeatin in $\varangle A \min \rrbracket$ cultivar produced the highest number of axillary shoot, main shoot length $(\mathrm{cm})$, and growth quality (Table 1$)$. In this study, there were no negative signs in $\triangle A m i n \rrbracket$ cultivar in high PGR MS. Different PGR concentrations had no impact on $\triangle$ Arbequina $₫$ and there was no special trend by increasing the zeatin concentration, (Table 1). $₫$ Meshkat $\$ plantlets were depressed by high zeatin concentration in both media enriched with $4 \mathrm{mg} / \mathrm{L}$ zeatin which with increment of zeatin only callus production as a negative factor increased (Tables 1 and 3). In $₫$ Meshkat $\llbracket$ cultivar, OM and MS containing $2 \mathrm{mg} / \mathrm{L}$ zeatin produced well-grown plantlets (Table 1). 
Table 1

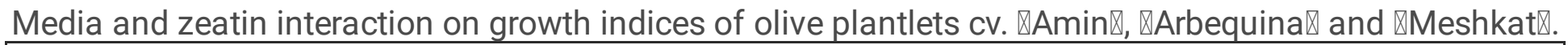

\begin{tabular}{|c|c|c|c|c|c|c|}
\hline Cultivar & Media & $\begin{array}{l}\text { Zeatin } \\
(\mathrm{mg} / \mathrm{L})\end{array}$ & $\begin{array}{l}\text { No. of } \\
\text { axillary } \\
\text { shoot }\end{array}$ & $\begin{array}{l}\text { Main shoot } \\
\text { length }(\mathrm{cm})\end{array}$ & $\begin{array}{l}\text { No. of leaves in } \\
\text { main shoot }\end{array}$ & $\begin{array}{l}\text { Growth } \\
\text { quality }\end{array}$ \\
\hline \multirow[t]{8}{*}{ 『Amin $\rrbracket$} & \multirow[t]{4}{*}{ OM } & 0 & $1.33 a b$ & 1.40 def & $4.16 \mathrm{~d}$ & $2.61 \mathrm{fg}$ \\
\hline & & 1 & $0.08 \mathrm{e}$ & $0.56 \mathrm{~g}$ & $5.64 \mathrm{bcd}$ & $1.09 \mathrm{~g}$ \\
\hline & & 2 & $0.32 \mathrm{de}$ & $0.51 \mathrm{~g}$ & $4.81 \mathrm{~cd}$ & $1.89 \mathrm{gh}$ \\
\hline & & 4 & $0.33 \mathrm{de}$ & $1.34 \mathrm{def}$ & $5.39 \mathrm{~cd}$ & $2.89 \mathrm{efg}$ \\
\hline & \multirow[t]{4}{*}{ MS } & 0 & 0.48 cde & $1.03 \mathrm{fg}$ & $7.11 \mathrm{abc}$ & $\begin{array}{l}3.36 \\
\text { cdef }\end{array}$ \\
\hline & & 1 & $0.75 \mathrm{bcd}$ & $1.48 \mathrm{cdef}$ & $8.47 \mathrm{ab}$ & $\begin{array}{l}3.48 \\
\text { cdef }\end{array}$ \\
\hline & & 2 & $0.78 \mathrm{bcd}$ & 1.48 cdef & $8.96 \mathrm{a}$ & 3.12 def \\
\hline & & 4 & $1.50 \mathrm{a}$ & $2.23 \mathrm{a}$ & $9.43 \mathrm{a}$ & $4.08 \mathrm{abc}$ \\
\hline \multirow{8}{*}{$\begin{array}{l}\mathbb{Q} \text { Arbequina } \\
\square\end{array}$} & \multirow[t]{4}{*}{$\mathrm{OM}$} & 0 & $0.17 \mathrm{de}$ & $1.83 \mathrm{abcd}$ & $8.57 \mathrm{ab}$ & $4.23 \mathrm{abc}$ \\
\hline & & 1 & $1.03 \mathrm{abc}$ & $2.11 \mathrm{ab}$ & $8.71 \mathrm{ab}$ & $4.55 \mathrm{ab}$ \\
\hline & & 2 & $0.75 \mathrm{bcd}$ & 1.62 bcde & $9.20 \mathrm{a}$ & $4.67 \mathrm{ab}$ \\
\hline & & 4 & $0.77 \mathrm{bcd}$ & $2.00 a b c$ & $9.26 \mathrm{a}$ & $4.80 \mathrm{a}$ \\
\hline & \multirow[t]{4}{*}{ MS } & 0 & 0.41 cde & 1.50 cdef & $7.36 \mathrm{abc}$ & $\begin{array}{l}3.49 \\
\text { cdef }\end{array}$ \\
\hline & & 1 & $0.11 \mathrm{e}$ & 1.20 ef & $6.61 \mathrm{abcd}$ & 2.80 efg \\
\hline & & 2 & $0.22 \mathrm{de}$ & $1.41 \mathrm{cde}$ & $8.39 a b$ & $\begin{array}{l}3.73 \\
\text { bcde }\end{array}$ \\
\hline & & 4 & $0.13 \mathrm{e}$ & $1.51 \mathrm{cdef}$ & $6.90 \mathrm{abcd}$ & 3.05 def \\
\hline \multirow[t]{7}{*}{ 『Meshkat $\rrbracket$} & \multirow[t]{4}{*}{ OM } & 0 & 0.48 cde & $1.05 \mathrm{fg}$ & $6.10 \mathrm{bcd}$ & $4.85 \mathrm{a}$ \\
\hline & & 1 & $0.75 \mathrm{bcd}$ & 1.35 def & $6.62 \mathrm{abcd}$ & $4.82 \mathrm{a}$ \\
\hline & & 2 & $1.48 \mathrm{a}$ & 1.43 cde & $7.32 \mathrm{abc}$ & $\begin{array}{l}3.74 \\
\text { bcde }\end{array}$ \\
\hline & & 4 & $0.14 \mathrm{e}$ & $1.06 \mathrm{fg}$ & $3.27 \mathrm{e}$ & 2.80 efg \\
\hline & \multirow[t]{3}{*}{ MS } & 0 & $0.33 \mathrm{de}$ & $1.22 \mathrm{ef}$ & $6.15 \mathrm{bcd}$ & $2.88 \mathrm{efg}$ \\
\hline & & 1 & $0.49 \mathrm{~cd}$ & 1.64 bcde & $6.17 \mathrm{bcd}$ & $4.84 \mathrm{a}$ \\
\hline & & 2 & $1.45 \mathrm{ab}$ & $1.84 \mathrm{abcd}$ & $6.93 \mathrm{abcd}$ & $4.90 \mathrm{a}$ \\
\hline
\end{tabular}




\begin{tabular}{|c|c|c|c|c|c|c|}
\hline Cultivar & Media & $\begin{array}{l}\text { Zeatin } \\
(\mathrm{mg} / \mathrm{L})\end{array}$ & $\begin{array}{l}\text { No. of } \\
\text { axillary } \\
\text { shoot }\end{array}$ & $\begin{array}{l}\text { Main shoot } \\
\text { length (cm) }\end{array}$ & $\begin{array}{l}\text { No. of leaves in } \\
\text { main shoot }\end{array}$ & $\begin{array}{l}\text { Growth } \\
\text { quality }\end{array}$ \\
\hline & & 4 & $0.25 \mathrm{de}$ & 1.60 bcde & $3.87 \mathrm{e}$ & 3.05 def \\
\hline
\end{tabular}

\section{Interactive effect of culturing system and genotype at proliferation stage}

The results showed that the most growth indices were higher in the periodical mini bioreactor (PMB) compared to semi-solid media (SSM) in $\triangle A m i n \bigotimes$ cultivar (Fig. 1). In all three culture media OM, MS and VS (Fig. 3) PMB system prominently showed the superiority, but growth quality in SSM and PMB of OM did not show any significant differences (Fig. 1).

The results showed that among growth indices in $\triangle$ Arbequina $\triangle$ cultivar only the number of axillary shoots was significantly higher in PMB compared to SSM. Suffocated plantlets resulted in a reduction in growth quality of plantlets in PMB were compared to SSM (Fig. 2).

Using $\mathrm{PMB}$ for $\mathrm{OM}$ in $\triangle \mathrm{Amin} \otimes$ cultivar improved main shoot length, but in $\triangle$ Arbequina $\triangle \mathrm{SSM}$ showed superiority in growth quality (Figs. 1 and 2 ). Regarding MS, main shoot length $(\mathrm{cm})$ plus growth quality in $\llbracket A m i n \rrbracket$ cultivar were superior in $\mathrm{PMB}$, but in $₫$ Arbequina $\$ the number of axillary shoot were significantly differences between PMB and SSM. Regarding VS, although in $\triangle A m i n \rrbracket$ cultivar it revealed absolute superiority in main shoot length, number of axillary shoot and growth quality using PMB, in $₫$ Arbequina $\$ cultivar it did not follow a specific trend (Figs. 1,2 and 3).

\section{Carbon and light source}

The number of axillary shoot, main shoot length and growth quality were significantly higher in medium

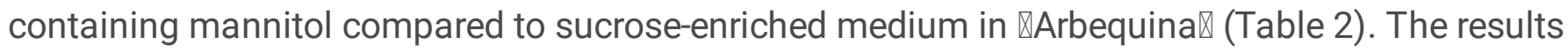
indicated that mannitol and sucrose induced $100 \%$ and $81.3 \%$ callus initiation at the base of explants, respectively (Table 3). In this study, at $2000 \mathrm{~cd} \cdot \mathrm{sr}^{-\mathrm{m}^{-2}}$ light intensity, plantlets' main shoot length, the number of axillary shoots and growth quality were enhanced, whereas number of main shoot leaves were not significantly different (Table 2). At $2000 \mathrm{~cd} \cdot \mathrm{sr}^{\mathrm{m}} \mathrm{m}^{-2}$, callus formation (87.5\%) was more than at 5000 cd.sr. $\mathrm{m}^{-2}$ treatment $(75 \%)$ (Table 3). 
Table 2

The simple effect of carbon source and light intensity on $₫$ Arbequina $\triangle$ growth indices

\begin{tabular}{|lllll|}
\hline Variable & No. of axillary & Main shoot length $(\mathbf{c m})$ & Main shoot leaves & Growth quality \\
\hline Mannitol & $0.9 \pm 0.2^{\mathrm{a}}$ & $3.5 \pm 0.1^{\mathrm{a}}$ & $10.3 \pm 0.4^{\mathrm{a}}$ & $5 \pm 0.04^{\mathrm{a}}$ \\
\hline Sucrose & $0.7 \pm 0.1^{\mathrm{b}}$ & $2.2 \pm 0.1^{\mathrm{b}}$ & $9 \pm 0.6^{\mathrm{b}}$ & $4.2 \pm 0.2^{\mathrm{b}}$ \\
\hline $2000 \mathrm{~cd} \cdot \mathrm{sr} \cdot \mathrm{m}^{-2}$ & $0.5 \pm 0.04^{\mathrm{a}}$ & $3 \pm 0.04^{\mathrm{a}}$ & $9.3 \pm 0.21^{\mathrm{a}}$ & $4.8 \pm 0.01^{\mathrm{a}}$ \\
\hline $5000 \mathrm{~cd} \cdot \mathrm{sr} \cdot \mathrm{m}^{-2}$ & $0.4 \pm 0.1^{\mathrm{b}}$ & $2.1 \pm 0.16^{\mathrm{b}}$ & $9.2 \pm 0.5^{\mathrm{a}}$ & $3.6 \pm 0.2^{\mathrm{b}}$ \\
\hline
\end{tabular}

Calli obtained from different media and genotype had different morphological characteristics like color and texture. In some cases, calli were green in color and strict solid in texture resulting in indirect organogenesis and their callus-differentiated shoots were morphologically healthy, but some of them were crystallized, spongy and vitrified which never gave rise to indirect shoot formation (Fig. 4).

\section{Callus formation at proliferation stage}

In $\triangle A$ Arbequina $\nabla$ and $\otimes$ Meshkat $\triangle$ cultivars, there was a direct correlation between zeatin concentration and callus formation, but in $\triangle A m i n \rrbracket$ there was no correlation in callus production (Table 3 ). In both $₫$ Arbequina $\triangle$ and $\triangle A$ min $\triangle$ cultivars, PMB produced significantly higher callus induction rates and volume than SSM.

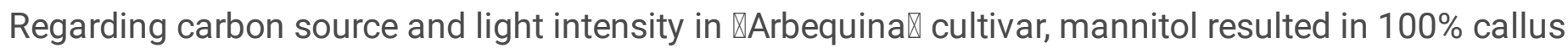
formation and $2000 \mathrm{~cd} \cdot \mathrm{sr} \cdot \mathrm{m}^{-2}$ produced more callus rather than $5000 \mathrm{~cd} \cdot \mathrm{sr} \cdot \mathrm{m}^{-2}$ (Table 3). 
Table 3

The effects of treatment and genotype on callus percent and callus volume

\begin{tabular}{|c|c|c|c|c|}
\hline Cultivar & Medium & Treatment & $\begin{array}{l}\text { Callus production } \\
\text { (\%) }\end{array}$ & $\begin{array}{l}\text { Callus volume } \\
\left(\mathrm{cm}^{3}\right)\end{array}$ \\
\hline \multirow[t]{8}{*}{$\triangle \operatorname{Amin} \rrbracket$} & \multirow[t]{4}{*}{$\mathrm{OM}$} & $\begin{array}{l}\text { Zeatin } 0 \\
(\mathrm{mg} / \mathrm{L})\end{array}$ & 59.4 & $1.26 \pm 0.12$ \\
\hline & & $\begin{array}{l}\text { Zeatin } 1 \\
(\mathrm{mg} / \mathrm{L})\end{array}$ & 57.15 & $1.52 \pm 0.13$ \\
\hline & & $\begin{array}{l}\text { Zeatin } 2 \\
(\mathrm{mg} / \mathrm{L})\end{array}$ & 59.4 & $1.94 \pm 0.16$ \\
\hline & & $\begin{array}{l}\text { Zeatin } 4 \\
(\mathrm{mg} / \mathrm{L})\end{array}$ & 60.25 & $2.53 \pm 0.21$ \\
\hline & \multirow[t]{4}{*}{ MS } & $\begin{array}{l}\text { Zeatin } 0 \\
(\mathrm{mg} / \mathrm{L})\end{array}$ & 87.5 & $1.89 \pm 0.16$ \\
\hline & & $\begin{array}{l}\text { Zeatin } 1 \\
(\mathrm{mg} / \mathrm{L})\end{array}$ & 62.5 & $2.34 \pm 0.21$ \\
\hline & & $\begin{array}{l}\text { Zeatin } 2 \\
(\mathrm{mg} / \mathrm{L})\end{array}$ & 68.8 & $2.51 \pm 0.17$ \\
\hline & & $\begin{array}{l}\text { Zeatin } 4 \\
(\mathrm{mg} / \mathrm{L})\end{array}$ & 30 & $1.94 \pm 0.23$ \\
\hline \multirow[t]{8}{*}{ 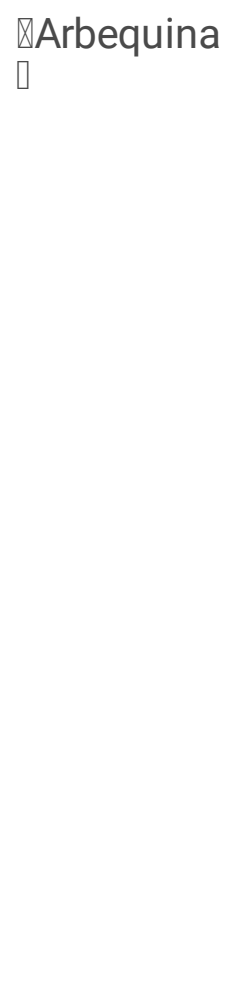 } & \multirow[t]{4}{*}{$\mathrm{OM}$} & $\begin{array}{l}\text { Zeatin } 0 \\
(\mathrm{mg} / \mathrm{L})\end{array}$ & 68.75 & $1.86 \pm 0.3$ \\
\hline & & $\begin{array}{l}\text { Zeatin } 1 \\
(\mathrm{mg} / \mathrm{L})\end{array}$ & 74.15 & $2.01 \pm 0.26$ \\
\hline & & $\begin{array}{l}\text { Zeatin } 2 \\
(\mathrm{mg} / \mathrm{L})\end{array}$ & 75.05 & $2.09 \pm 0.26$ \\
\hline & & $\begin{array}{l}\text { Zeatin } 4 \\
(\mathrm{mg} / \mathrm{L})\end{array}$ & 84.4 & $2.17 \pm 0.03$ \\
\hline & \multirow[t]{4}{*}{ MS } & $\begin{array}{l}\text { Zeatin } 0 \\
(\mathrm{mg} / \mathrm{L})\end{array}$ & 50 & $1.83 \pm 0.15$ \\
\hline & & $\begin{array}{l}\text { Zeatin } 1 \\
(\mathrm{mg} / \mathrm{L})\end{array}$ & 43.8 & $1.91 \pm 0.13$ \\
\hline & & $\begin{array}{l}\text { Zeatin } 2 \\
(\mathrm{mg} / \mathrm{L})\end{array}$ & 56.3 & $2.18 \pm 0.12$ \\
\hline & & $\begin{array}{l}\text { Zeatin } 4 \\
(\mathrm{mg} / \mathrm{L})\end{array}$ & 68.8 & $2.56 \pm 0.02$ \\
\hline \Meshkat】 & $\mathrm{OM}$ & $\begin{array}{l}\text { Zeatin } 0 \\
(\mathrm{mg} / \mathrm{L})\end{array}$ & 15 & $0.74 \pm 0.21$ \\
\hline
\end{tabular}




\begin{tabular}{|c|c|c|c|c|}
\hline Cultivar & Medium & Treatment & $\begin{array}{l}\text { Callus production } \\
(\%)\end{array}$ & $\begin{array}{l}\text { Callus volume } \\
\left(\mathrm{cm}^{3}\right)\end{array}$ \\
\hline & & $\begin{array}{l}\text { Zeatin } 1 \\
(\mathrm{mg} / \mathrm{L})\end{array}$ & 27.5 & $1.45 \pm 0.34$ \\
\hline & & $\begin{array}{l}\text { Zeatin } 2 \\
(\mathrm{mg} / \mathrm{L})\end{array}$ & 35 & $1.53 \pm 0.13$ \\
\hline & & $\begin{array}{l}\text { Zeatin } 4 \\
(\mathrm{mg} / \mathrm{L})\end{array}$ & 67.5 & $2.76 \pm 0.41$ \\
\hline & MS & $\begin{array}{l}\text { Zeatin } 0 \\
(\mathrm{mg} / \mathrm{L})\end{array}$ & 10 & $0.80 \pm 0.14$ \\
\hline & & $\begin{array}{l}\text { Zeatin } 1 \\
(\mathrm{mg} / \mathrm{L})\end{array}$ & 30 & $0.80 \pm 0.11$ \\
\hline & & $\begin{array}{l}\text { Zeatin } 2 \\
(\mathrm{mg} / \mathrm{L})\end{array}$ & 35 & $0.82 \pm 0.07$ \\
\hline & & $\begin{array}{l}\text { Zeatin } 4 \\
(\mathrm{mg} / \mathrm{L})\end{array}$ & 65 & $0.85 \pm 0.27$ \\
\hline \multirow[t]{6}{*}{$\llbracket \operatorname{Amin} \rrbracket$} & \multirow{2}{*}{$\begin{array}{l}\mathrm{OM}+2 \mathrm{mg} / \mathrm{L} \\
\text { zeatin }\end{array}$} & PMB & 100 & $2.25 \pm 0.40$ \\
\hline & & SSM & 70 & $2.03 \pm 0.14$ \\
\hline & \multirow{2}{*}{$\begin{array}{l}\mathrm{MS}+2 \mathrm{mg} / \mathrm{L} \\
\text { zeatin }\end{array}$} & PMB & 80 & $1.44 \pm 0.20$ \\
\hline & & SSM & 20 & $0.12 \pm 0.14$ \\
\hline & \multirow[t]{2}{*}{$\mathrm{VS}+2 \mathrm{mg} / \mathrm{L}$ zeatin } & PMB & 80 & $1.19 \pm 0.17$ \\
\hline & & SSM & 60 & $0.9 \pm 0.14$ \\
\hline \multirow{9}{*}{$\mathbb{\nabla}$ Arbequina } & \multirow{2}{*}{$\begin{array}{l}\mathrm{OM}+2 \mathrm{mg} / \mathrm{L} \\
\text { zeatin }\end{array}$} & PMB & 70 & $2.0 \pm 0.26$ \\
\hline & & SSM & 70 & $1.98 \pm 0.24$ \\
\hline & \multirow{2}{*}{$\begin{array}{l}\mathrm{MS}+2 \mathrm{mg} / \mathrm{L} \\
\text { zeatin }\end{array}$} & PMB & 70 & $3.50 \pm 0.11$ \\
\hline & & SSM & 10 & $3.30 \pm 0.23$ \\
\hline & \multirow[t]{2}{*}{$\mathrm{VS}+2 \mathrm{mg} / \mathrm{L}$ zeatin } & PMB & 60 & $3.70 \pm 0.17$ \\
\hline & & SSM & 40 & $1.10 \pm 0.12$ \\
\hline & \multirow{2}{*}{$\begin{array}{l}\mathrm{OM}+1 \mathrm{mg} / \mathrm{L} \\
\text { zeatin }\end{array}$} & Mannitol & 100 & $3.25 \pm 0.3$ \\
\hline & & Sucrose & 81.3 & $1.78 \pm 0.28$ \\
\hline & $\begin{array}{l}\mathrm{OM}+1 \mathrm{mg} / \mathrm{L} \\
\text { zeatin }\end{array}$ & $2000 \mathrm{~cd} \cdot \mathrm{sr} \cdot \mathrm{m}^{-2}$ & 87.5 & $1.88 \pm 0.06$ \\
\hline
\end{tabular}




\begin{tabular}{|c|c|c|c|c|}
\hline Cultivar & Medium & Treatment & $\begin{array}{l}\text { Callus production } \\
\text { (\%) }\end{array}$ & $\begin{array}{l}\text { Callus volume } \\
\left(\mathrm{cm}^{3}\right)\end{array}$ \\
\hline & & $5000 \mathrm{~cd} \cdot \mathrm{sr} \cdot \mathrm{m}^{-2}$ & 75 & $1.69 \pm 0.24$ \\
\hline
\end{tabular}

From 12 primer combinations tested, 259 bands ( $50 \mathrm{bp}$ to $1000 \mathrm{bp}$ ) were analyzed in all tested cultivars consisting of MIS and CIS with 238 bands were polymorphic. Polymorphism rate varied from $39.02 \%$ for EAGG- MGC to $100 \%$ for EAGC- MCAA. Each primer pair resulted in 28 to 55 markers with an average of 42 amplified fragments (Table 4). 
Table 4

Primer combinations and polymorphism rate.

\begin{tabular}{|c|c|c|c|c|}
\hline $\begin{array}{l}\text { Primer } \\
\text { combination }\end{array}$ & Primer sequence $\left(5^{\prime}\right.$ to $\left.3^{\prime}\right)$ & $\begin{array}{l}\text { Total number } \\
\text { of bands }\end{array}$ & $\begin{array}{l}\text { Number of } \\
\text { polymorphic } \\
\text { bands }\end{array}$ & $\begin{array}{l}\text { Polymorphism } \\
\text { rate (\%) }\end{array}$ \\
\hline \multirow[t]{2}{*}{ EAGG- MGT } & GACTGCGTACCAATTCAGG & 37 & 28 & 75.67 \\
\hline & GATGAGTCCTGAGTAAGT & & & \\
\hline \multirow[t]{2}{*}{ ECT-MGAG } & GACTGCGTACCAATTCCT & 45 & 42 & 93.33 \\
\hline & GATGAGTCCTGAGTAAGAG & & & \\
\hline \multirow[t]{2}{*}{ ECT- MGC } & GACTGCGTACCAATTCCT & 37 & 32 & 86.48 \\
\hline & GATGAGTCCTGAGTAAGC & & & \\
\hline \multirow[t]{2}{*}{ EAGC- MCAA } & GACTGCGTACCAATTCAGC & 50 & 50 & 100 \\
\hline & GATGAGTCCTGAGTAACAA & & & \\
\hline \multirow[t]{2}{*}{ MGT-ETA } & GATGAGTCCTGAGTAAGT & 33 & 27 & 81.81 \\
\hline & GACTGCGTACCAATTCTA & & & \\
\hline \multirow[t]{2}{*}{ MGC- ETA } & GATGAGTCCTGAGTAAGC & 55 & 25 & 45.45 \\
\hline & GACTGCGTACCAATTCTA & & & \\
\hline \multirow[t]{2}{*}{ EGA- MCAT } & GACTGCGTACCAATTCGA & 39 & 34 & 87.17 \\
\hline & GATGAGTCCTGAGTAACAT & & & \\
\hline \multirow[t]{2}{*}{ MCT- EAGG } & GATGAGTCCTGAGTAACT & 28 & 21 & 75 \\
\hline & GACTGCGTACCAATTCAGG & & & \\
\hline \multirow[t]{2}{*}{ MCAG- EAT } & GATGAGTCCTGAGTAAGA & 71 & 63 & 88.73 \\
\hline & GACTGCGTACCAATTCAT & & & \\
\hline \multirow[t]{2}{*}{ EAGG- MCAG } & GACTGCGTACCAATTCAGG & 28 & 25 & 89.28 \\
\hline & GATGAGTCCTGAGTAAGA & & & \\
\hline \multirow[t]{2}{*}{ EAGG- MTTT } & GACTGCGTACCAATTCAGG & 35 & 16 & 45.71 \\
\hline & GATGAGTCCTGAGTAATTT & & & \\
\hline \multirow[t]{2}{*}{ EAGG- MGC } & GACTGCGTACCAATTCAGG & 41 & 16 & 39.02 \\
\hline & GATGAGTCCTGAGTAAGC & & & \\
\hline
\end{tabular}




\begin{tabular}{|lllll|}
\hline $\begin{array}{l}\text { Primer } \\
\text { combination }\end{array}$ & Primer sequence $\left(\mathbf{5}^{\prime}\right.$ to $\left.\mathbf{3}^{\prime}\right)$ & $\begin{array}{l}\text { Total number } \\
\text { of bands }\end{array}$ & $\begin{array}{l}\text { Number of } \\
\text { polymorphic } \\
\text { bands }\end{array}$ & $\begin{array}{l}\text { Polymorphism } \\
\text { rate (\%) }\end{array}$ \\
\hline Total & 499 & 379 & 75.95 \\
\hline Genetic similarity & & & \\
\hline
\end{tabular}

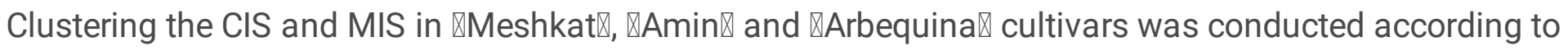
the genetic similarity SAHN, method UPGMA and tie WARN. The phylogenetic analysis splitted the samples into 8 distinct groups indicating that callus-regenerated plants had highly monomorphic amplicons similar to those of the meristem-regenerated plants (Fig. 5). Cophenetic correlation coefficient was $(r=0.80)$ and based on Jaccard's coefficient, similarity matrix and the pair-wise value between the CIS and MIS showed similarity levels at 62-98\%. Marker analysis showed that genotype was the most

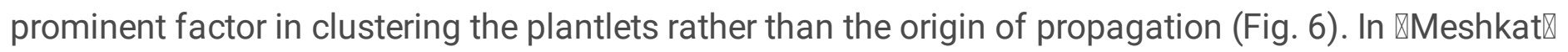
cultivar no matter the origin of regeneration (meristem or callus), each sample had the most resemblance with other samples of its cultivar according to the similarity coefficient factor, Jaccard and Dice (Fig. 6).

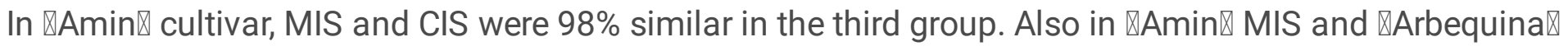
MIS more than $97 \%$ resemblance was seen. This group was the only group that consisted of both $₫ A \min \rrbracket$

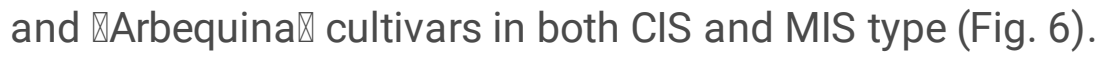

One of the callus induced samples in $₫$ Arbequina $₫$ cultivar appeared in a separate branch of phylogenetic tree which was similar to all groups consisting 3 cultivars with $63 \%$ genetic similarity and one of its MIS samples appeared in a separate category with $79 \%$ resemblance with both CIS and MIS of $₫$ Meshkat $\gtrsim$. It

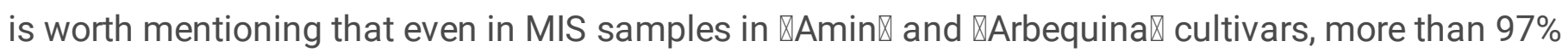

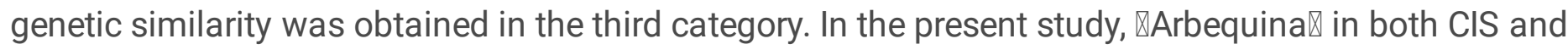
MIS showed the most dispersal in classification, but both Iranian cultivars showed more stability (Fig. 6).

\section{FCM assessment of CIS and MIS}

Simultaneous analysis of nuclei isolated from Parsley (Petroselinum crispum) (2C DNA amount =

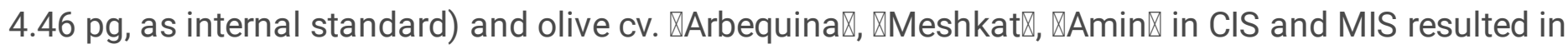
highly reproducible histograms with P1/P2 ratio and low CV value which approved the priority of cultivar rather than the origin of propagation in genetic similarity, consequently there were no differences between the studied cultivars (Table 5). Moreover, there was no discrepancy between CIS and MIS in total DNA amount (2.87-3.12 pg) (Table 5). Figure 7 illustrates a representative of FCM histograms for CIS and MIS in $\varangle$ Meshkat $\nabla$ cultivar which indicate the similarity between the peak ${ }_{1} /$ peak $_{2}$ ratios (mode $P_{1} / P_{2}=0.67$ ) in both CIS and MIS. 
Table 5

DNA amounts in $₫ A m i n \rrbracket, ~ \bigotimes$ Meshkat $\$ and $₫$ Arbequina $\$ cultivars regenerated from callus and meristem

\begin{tabular}{|c|c|c|c|}
\hline Cultivar & Type of origin & $\mathrm{P} 1 / \mathrm{P} 2$ & DNA amount (pg) \\
\hline \multirow[t]{2}{*}{$\llbracket \operatorname{Amin} \rrbracket$} & CIS & $0.67 a$ & $2.99 \pm 0.01$ \\
\hline & MIS & $0.68 \mathrm{a}$ & $3.02 \pm 0.01$ \\
\hline \multirow[t]{2}{*}{$\llbracket$ Meshkat $\rrbracket$} & CIS & $0.67 \mathrm{a}$ & $3.01 \pm 0.01$ \\
\hline & MIS & $0.64 a$ & $2.87 \pm 0.05$ \\
\hline \multirow[t]{2}{*}{ 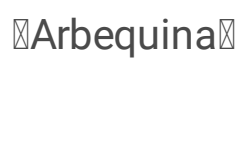 } & CIS & $0.70 \mathrm{a}$ & $3.12 \pm 0.02$ \\
\hline & MIS & $0.66 a$ & $2.95 \pm 0.03$ \\
\hline
\end{tabular}

\section{Discussion}

\section{Effects of zeatin concentration and cultivar on growth indices at proliferation stage}

Benelli and De Carlo (2018) reported that zeatin $(10 \mu \mathrm{M})$ not only affected axillary shoot induction of olive but also it stimulated shoot length. Another study reported that $18.4 \mu \mathrm{M}$ of zeatin caused a negative effect on olive growth indices (Haddad et al., 2018). Ali et al. (2009) showed that $4 \mathrm{mg} / \mathrm{L}$ zeatin caused an acceptable microshoot formation of olive in comparison with 1,2 and $3 \mathrm{mg} / \mathrm{L}$ zeatin. Zeatin is the best cytokinin enhancing shoot formation and even length development in olive which affects cell expansion. High zeatin concentration reduced shoot proliferation and elongation which are genotypedependent (Haddad et al., 2018). Since supra optimal concentration of cytokinins had a low interaction with minerals in the media, shoot length depression occurred in sub optimal and supra optimal concentrations (Ali et al., 2009).

It is showed that combined cytokinins in olive increased the proliferation rate (Moradnezhad et al., 2017), zeatin in combination with other cytokinins like BAP, a fixed compound of media in this study was used to have synergistic effect on proliferation improvement as well. In $₫$ Moraioloखoraioloation improvementsed to havetokinins like BAPPgth depression occur冈 cultivs betweemicroshoot formation (Ali et al., 2009). In other subspecies of olive (Laperrine olive), regeneration was to a high extent related to media and PGRs and only in case of not applying PGRs, microshoot formation did not develop (Haddad et al., 2018). Zeatin plus carbon source might have an effect on complex plant signaling network (Leva et al., 2013).

\section{Interactive effect of culturing system and genotype at proliferation stage}


Apical dominance and oxidized tannins from phenolic compounds in semi-solid media inhibited the normal regeneration in olive (Rugini, 1984; Sadder, 2002). Using bioreactor is advantageous because of lower production cost due to reducing the labor, zeatin concentration and increased efficiency of proliferation rate plus removing gelling agent (Benelli and De Carlo, 2018). A novel temporary immersion system was reported to be a suitable method in olive micropropagation in comparison with other liquid systems such as Erlenmeyer flasks, filter paper bridges in test tubes and LifeReactor (Grigoriadou et al., 2005). The advantage of liquid system is due to lowering the toxic compound aggregation, well aerated plantlets (Benelli and De Carlo, 2018; Sadder, 2002) and horizontal position of plantlets. This method allows reduction in carbon dioxide, ethylene gases and relative humidity in the vessel's headspace and thus reduces morphogenesis abnormality (Benelli and De Carlo, 2018). They showed using plantform ${ }^{\mathrm{Tm}}$ bioreactor, desired zeatin concentration in olive was reduced to $25-50 \%$. In the present study, PMB

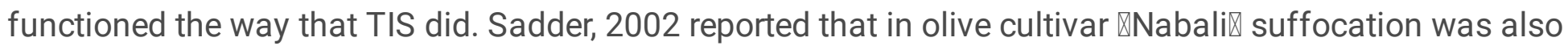
reported in liquid OM (Sadder, 2002).

Analysis of 4-5 cm of olive shoot tip by Rugini (1984) resulted in introducing the best medium for olive micropropagation called OM which is high in $\mathrm{Ca}, \mathrm{Mg}, \mathrm{S}, \mathrm{Cu}$ and $\mathrm{Zn}$. Mg which is triple higher in OM compared to MS and VS (Duchefa, NL) increased shoot elongation by affecting enzymes positively, especially those involved in phosphate transfer as modulator of shoot initiation and growth promoter (Shaul, 2002). Nevertheles, it has as twice Boron as MS and VS have which evidently plays important roles in nucleic acid synthesis, cell differentiation and elongation (Läuchli, 2002).

VS medium contains macro elements as described by Murashige and Skoog (1962) and contains chelated Fe form EDDHA instead of EDTA as described by Van der Salm et al. (1994) which provides a better iron supply at higher $\mathrm{pH}$ and phosphate content since it is much stronger than Fe-EDTA (Duchefa,

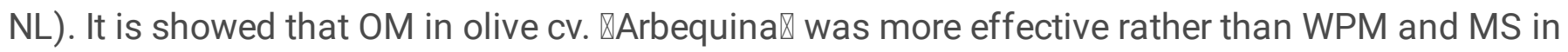
producing total number of shoots and healthy plantlets (Moradnezhad et al., 2017). Different

fundamental formulations are required for olive's genotypes (Moradnezhad et al., 2017; Rugini, 1984), as minerals may sensitize cells to PGRs and nutrient mobilization occurs in PGRs existence by creating new source sink relationship. High calcium $\left(\mathrm{CaCl}_{2}\right.$ and $\left.\mathrm{Ca}\left(\mathrm{NO}_{3}\right)_{2}\right)$ in $\mathrm{OM}$ plays a role in cytokinin signal transduction in cells which leads to better cell division (Ali et al., 2009). Folic acid co-enzymes are involved in carbon transfer, which are vital for methionine, serine, deoxythimidylic acid and purines synthesize that are necessary for cell differentiation (Ali et al., 2009).

\section{Carbon and light sources}

Leva et al. (2013) showed more undifferentiated parenchyma-like callus growth in medium containing sucrose rather than medium enriched with mannitol. Haddad et al. (2018) reported mannitol resulted in greener foliage and morphologically healthy plantlets similar to their mother plants. It is proved that shoot development pattern, plantlet survival, growth quality and secondary shoot formation in olive are affected by carbon sources (Leva et al., 2013). Starch, mannitol and sucrose are the most carbohydrates 
in olive and soluble sugar mannitol is predominant in leaves and branches twice as abundance as sucrose (Bustan et al., 2011) which contains $30 \%$ of olive total carbohydrates (Flora and Madore, 1993) and varies according to the year of bearing (on or off year), season as mannitol peaks is related to high temperature in summer, olive's organs and even fruit harvesting time (Bustan et al., 2011). In olive, subsequent sub-culturing (seven times) in media containing mannitol increased the survival rate approximately twice compared with sucrose (Leva et al., 2013). Mannitol promoted bud sprouting and secondary shoot uniformity rather than sucrose regardless of its concentration (Leva et al., 2013). Mannitol may directly and indirectly influence endogenous hormonal status protecting against detrimental compounds in media (Leva et al., 2013) in contraction with sucrose in higher concentrations. As mannitol is involved in activating osmotic effect, plants with high amount of mannitol or wellacclimatized in mannitol enriched media have negligible osmotic stresses (Moradnezhad et al., 2017). Moreover, mannitol transfer in intracellular metabolism aids olive against abiotic stresses by acting as a supportive agent against olive cell suspension dehydration (Leva et al., 2013). In catabolism of mannitol in sink cells, hexose phosphate generates 2 ATP molecules, while initial generation of hexose phosphate in catabolism of sucrose spends ATP, so that energetic advantages of mannitol might be used for exponential growth (Leva et al., 2013; Moradnezhad et al., 2017).

In stevia, shoot induction occurred more frequently in $6000 \mathrm{~cd} \cdot \mathrm{sr}^{\mathrm{r}} \cdot \mathrm{m}^{-2}$ intensity rather than 2000 and 4000 $\mathrm{cd} \cdot \mathrm{sr} \cdot \mathrm{m}^{-2}$ under the controlled situation. Light intensity affected stevia organogenesis as well and 6000 $\mathrm{cd} \cdot \mathrm{sr} \cdot \mathrm{m}^{-2}$ was suitable for axillary shoot formation (Roshandel et al., 2013). In Ternstroemia gymnanthera three light intensities $\left(500,1000,2000 \mathrm{~cd} \cdot \mathrm{sr}^{\mathrm{m}} \cdot \mathrm{m}^{-2}\right)$ were compared and the results showed 1000-2000 $\mathrm{cd} \cdot \mathrm{sr} \cdot \mathrm{m}^{-2}$ were more acceptable in growth quality and in case of LED light and fluorescent lamp the most proper luminous intensity was $2000 \mathrm{~cd} \cdot \mathrm{sr}^{\mathrm{m}} \mathrm{m}^{-2}$ (Ahn and Choi, 2016) similar to this study findings.

Callus is normally regenerated due to zeatin application in the proximal end of plantlets and at the end of petioles which is a common reaction to in vitro stresses. It was reported that OM induced callus in olive without additional PGRs (Sadder, 2002) however, callus organogenesis only occurred in special olive

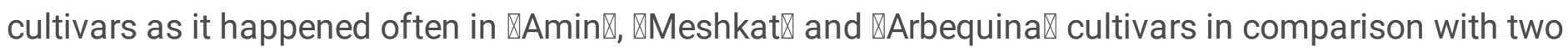

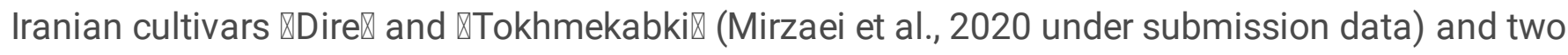

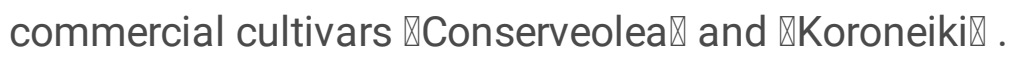

\section{Callus formation at proliferation stage}

Krishna et al. (2016) reported that making wound in cutting samples, auxin and auxin analogs, sterilization and PGRs can cause mutagenesis and also, salts, temperature and light changes can result in oxidative stresses. Consequently, superoxide, hydrogen peroxide, hydroxyl, peroxyl and alkoxyl compounds can cause hyper/hypo methylation of DNA, DNA base deletion and substitution, chromosomal rearrangement and number change, which in turn resulting in mutation and somaclonal variation in in vitro culture (Bradaï et al., 2016; Krishna et al., 2016). 


\section{Molecular assessment of CIS and MIS in three cultivars}

In order to further assess the olive genome coverage, several primers should be tested to increase the number of loci. It was previously stated that phenotypical, cytological and biochemical methods can be used in this purpose, though molecular assessment repetition in another growth phase is desirable (Bradaï et al., 2019) because somatical genetic stability of olive scarcely was studied so far. SSR was not informative in olive genetic variation assessment since replication slippage was more frequent that might ignore single nucleotide mutation (Bradaï et al., 2019), so that AFLP was chosen because its discriminating capacity was proved in analyzing olive cultivars (Belaj et al., 2003).

Nearly $97 \%$ resemblance between $₫$ Amin $₫$ MIS and $₫$ Arbequina $₫$ MIS was seen proving that the resemblance between these genotypes for stem cutting in vitro culture was considered stable (Brito et al., 2010), consequently they were genetically close to each other (Bradaï et al., 2019 and 2016).

Embryogenic culture-induced olives from the same cotyledon maintained in in vitro conditions for 3 years showed genetic instability due to the long term maintenance (Bradaï et al., 2019). Although variation in olive was reported slightly higher in aged plants in vitro subcultured continually, it was highly genotypedependent and biometric analysis of quantitative traits also showed intraclonal variation. Haddad et al. (2018) reported all amplicons in ISSR marker between regenerated diploid and triploid endangered olive in comparison with donor plants were monomorph, so that all the regenerants in high PGRs and their mother plants were grouped in the same category (Haddad et al., 2018). Nevertheless, as the stability of in vitro-raised olives in OM and zeatin enriched media was proved (Haddad et al., 2018), in this study MIS was considered as donor plants and CIS was compared to MIS. On the other hand, Guillaume et al., (2009) reported that meristem mutation position was the first important factor in chimerism maintenance and mutation in apical dome normally resulted in permanent chimera (Besnard and Baali-Cherif, 2009). In marker investigations, DNA is usually extracted from leaves and so, the mutation level in diploids might be underestimated (Besnard and Baali-Cherif, 2009). Nevertheless sampling after 6 subcultures could resolve such a problem as the results of this study showed.

No correlation between genetically somaclonal varied plants with phenotypic changes was found as phenotypical characteristics are controlled by several genes (Bradaï et al., 2019), moreover special part of this genuine variation might be due to the differences in non-coding portion of genome, which might not be expressed and revealed in olive appearance and performance. To reduce such controversial issues, complementary phenotypic analysis is recommended (Bradaï et al., 2016). Provoked changes in cells might also result in developmental reprogramming in plants (Belaj et al., 2003; Bradaï et al., 2019). The problem of undesired callus induction at the basal end and petiole end part in olive propagation was reported frequently. Callus phase is a prerequisite of variations. Studies on genetic stability in somaclonal varied olives are scarce (Bradaï et al., 2019), therefore this is the first study that compared plantlets originated from MIS and CIS as genetic stability and ploidy level fidelity in olive. Belaj et al. (2003) stated that the combination of two different genetic change assessments in olive is another approach and so, evaluation of ploidy level changes by FCM was used. 


\section{FCM assessment CIS and MIS}

In this study DNA amounts were similar to olives measured previously (2.90-3.07 pg) (Loureiro et al., 2007). There was no significant nuclear DNA content difference among cultivars. Nonetheless, in the previous studies DNA amount fluctuation might be attributed to the cytosolic compounds like phenols causing tannic acid effect as a result of interference with DNA-PI staining since there is an abundant amount of such materials in woody plants (Loureiro et al., 2007). These interfering phenolic compounds are genotype-dependent and normally micropropagated plants accumulate higher amounts of cytosolic compounds which do not allow proper PI staining resulting in lower DNA amount (Loureiro et al., 2007). Even though olive is extremely high in such mentioned interferer compounds and its discrepancy in DNA $2 \mathrm{C}$ value should be considered cautiously, fortunately in the present study interferer materials were not problematic. PVP was added to nuclei isolation buffer to solve such problematic issues in secondary metabolites (Loureiro et al., 2007). Not severely chopped leaves by razor blade can also equilibrate interferer material (Loureiro et al., 2007).

Loureiro et al. (2007) reported that $2 \mathrm{C}$ DNA content of 0 . europaea ssp. europaea var. europaea ranged between $2.90 \pm 0.020 \mathrm{pg} / 2 \mathrm{C}$ and $3.07 \pm 0.018 \mathrm{pg} / 2 \mathrm{C}$ and for wild olive, it was $3.19 \pm 0.047 \mathrm{pg} / 2 \mathrm{C}$. In this study, $84 \%$ of samples had lower DNA amounts. Ploidy level changes are prominent processes in plant evolution. Due to reduction in inbreeding depression effect, triploids are much more vigorous than diploids especially in extreme situations and as $₫ A \min \rrbracket$ was highly resistance to salinity stress and other abiotic stresses (data are not shown), it was suspected to be a polyploid which was not proven in this study as previously reported for Iranian olive cultivars and checking other genetic variation disorder in this genotype is recommended.

\section{Conclusion}

It was proved that the most optimized protocols (PMB, mannitol carbon source and $2000 \mathrm{~cd} \cdot \mathrm{sr}^{\mathrm{r}} \cdot \mathrm{m}^{-2}$ light intensity) normally co-produced larger calli both in percent and volume: resulting in more undesired indirect organogenesis. To verify true to typeness of CIS, genetic stability was assessed using AFLP and FCM. The results showed that no DNA amount change happened. Nonetheless, in marker analysis

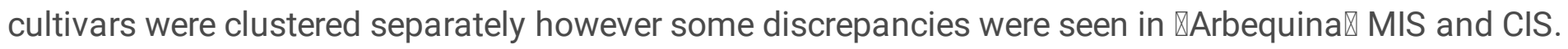

\section{Methods}

\section{Plant materials and general procedures}

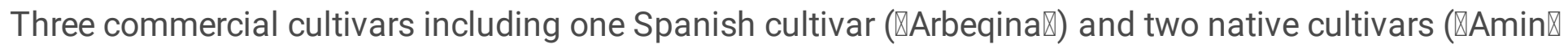
and $\triangle$ Meshkat $\triangle$ ) were selected. The huge number of semi-hard cuttings with apical and lateral buds consisting of axillary buds were collected in July from mature trees grown in olive collection at Tarom Olive Research Station (Tarom, Zanjan) in Iran. Explants with at least 2 opposite nodes $(2 \mathrm{~cm})$ were surface sterilized in $70 \%$ ethanol $(\mathrm{v} / \mathrm{v})$ for $60-75$ seconds followed by agitating in $2.5 \%$ sodium 
hypochlorite containing 1\% Tween- 20 for 13 min, then three times washing in sterilized distilled water each time for 5 min.

At establishment stage, a large number of explants were cultivated on OM (Olive medium, Duchefa, NL) supplemented with $4 \mathrm{mg} / \mathrm{L}$ zeatin (Duchefa, $\mathrm{NL}$ ) plus $0.5 \mathrm{mg} / \mathrm{L}$ 2ip (6-ү Y-Dimethylallylaminopurine) (Duchefa, NL) in order to have enough source for experiments.

All media including solid and liquid were enriched with $3 \%(\mathrm{w} / \mathrm{v})$ sucrose (unless otherwise stated) and $0.5 \mathrm{mg} / \mathrm{L} 2 \mathrm{ip}+0.23 \mathrm{mg} / \mathrm{L} \mathrm{BAP}+0.04 \mathrm{mg} / \mathrm{L} \mathrm{IBA}+540 \mathrm{mg} / \mathrm{L}$ calcium gluconate $+50 \mathrm{mg} / \mathrm{L} \mathrm{FeEDDHA}+$ $4 \mathrm{mg} / \mathrm{L} \mathrm{H}_{3} \mathrm{Bo}_{3}$ and $\mathrm{pH}$ was adjusted to 5.8. Then were solidified with $0.7 \%(\mathrm{w} / \mathrm{v})$ plant agar (Duchefa, $\mathrm{NL}$ ). All media and glassware were autoclaved for $15 \mathrm{~min}$ at $121^{\circ} \mathrm{C}$ and 1.37 bar. Phytotrons with high pressure metal halide lamps $\left(2609 \mathrm{~cd} \mathrm{sr} \mathrm{m}^{-2}\right)$ and $16 / 8$ hour light/dark cycle and temperature of $24 \pm 1{ }^{\circ} \mathrm{C}$ were used to maintain the cultures. Olive growth indices the most important of which axillary shoot number, leaf number, shoot length and callusing were measured and recorded in all experiments. At least 25 repetitions of each treatment were averaged.

\section{Interactive effects of cultivar, culture media and zeatin concentration at proliferation stage}

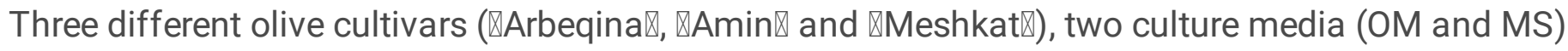
(Murashigue and Skoog, 1962) and various zeatin concentrations $(0,1,2$ and $4 \mathrm{mg} / \mathrm{L}$ ) were added to basal studied media (Plant materials and general procedures).

\section{Application of Periodical Mini Bioreactor (PMB) at proliferation stage}

Two cultivars ( $\triangle A$ Amin $\rrbracket$ and $₫$ Arbequina $\bigotimes$ ) under different culture media (OM, MS and VS) (van Der Salm, 1994) containing $2 \mathrm{mg} / \mathrm{L}$ zeatin beside the previously mentioned additives (Plant materials and general procedures) in two forms of semi-solid media (SSM) and liquid were investigated. VS was included in this experiment, because in another study of mine, olive cv. Amin was reacted well to it (Mirzaei et al., 2019).

Autoclaved periodical mini bioreactors (BPM; bioreactor D 345, AZMAYESH ABZAR DI 2413, IR) were filled with $300 \mathrm{~mL}$ of sterilized liquid medium (Fig. 8). Ten explants with three replications were placed in the inner jars and periodically immersed in the liquid medium. The compressed air passed through two $0.2 \mu \mathrm{m}$ micropore filters providing additional protection. The nutrition program in $24 \mathrm{~h}$ included three times immersion (each time $10 \mathrm{~min}$ ) followed by three times drainage and aeration (each time $10 \mathrm{~min}$ ) and stationary stage (each time $7 \mathrm{~h}$ and $40 \mathrm{~min}$ ). 


\section{Effect of carbon source and light intensity at proliferation stage}

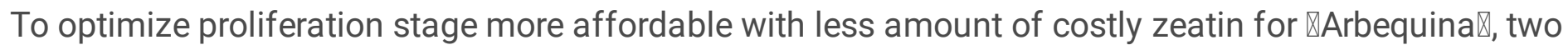
carbon sources (sucrose and mannitol) and two different light intensities (2000 and $5000 \mathrm{~cd} \cdot \mathrm{sr}^{\mathrm{m}} \mathrm{m}^{-2}$ ) in OM containing $1 \mathrm{mg} / \mathrm{L}$ zeatin plus previously mentioned additives (Plant materials and general procedures) for 25 sample repetition ( 5 glass jars and 5 sample per each), to separate experiments were carried out.

\section{Genetic stability in callus induced shoots (CIS) and meristem induced shoots (MIS)}

Since large masses of calli at the basal part of shoot explants in most olive proliferation experiments were created, therefore, callus formation percent and callus volume $\left(\mathrm{cm}^{3}\right)$ were recorded. For volume measurement, sphere volume $\left(4 / 3 \pi r^{3}\right)$ for approximately spheral calli and immersion in graduated cylinder half filled with water for multi- dimensional calli were used. To confirm the similarity of microshoots originated from calli (CIS) and shoots originated from meristems (MIS), Amplified Fragment Length Polymorphism (AFLP) and Flow cytometry (FCM) were used. The shoots were cultured on their optimized culture media (Table 1) for 6 months while sub-cultured every 6 weeks. During this experiment, CIS samples equal to their counterpart MIS were marked and subcultured separately, in order to check their similarity. Repetitions are mentioned in each experiment.

\section{Amplified Fragments Length Polymorphism (AFLP)}

Total genomic DNA was extracted from $200 \mathrm{mg}$ of fresh tissue of in vitro plant leaves of both MIS and CIS following the Cetyl Trimethyl Ammonium Bromide (CTAB) method (Doyle and Doyle, 1987). DNA concentration and quality were evaluated by $1 \%$ agarose gel electrophoresis and NanoDrop (Implen, DE). The AFLP technique was carried out as described by Vos et al., (1995) with the following modifications: $500 \mathrm{ng}$ of genomic DNA of 17 samples with 4 replications were double digested using 5 units of EcoRI and Msel enzymes, and adaptors were ligated to the obtained fragments. The ligation mixture was diluted 1:4 with nuclease-free water, and $3.75 \mu \mathrm{L}$ of it was used for PCR pre-amplification in a $25 \mu \mathrm{L}$ volume with 10 picomol of each pre-amplification primer carrying three selective nucleotides. After 2 min at $72{ }^{\circ} \mathrm{C}, 20$ cycles were carried out at $95^{\circ} \mathrm{C}$ for $30 \mathrm{~s}, 55^{\circ} \mathrm{C}$ for $30 \mathrm{~s}$ and $72{ }^{\circ} \mathrm{C}$ for $60 \mathrm{~s}$ in Thermocycler (Applied Biosystems, USA). A total of 12 primer combinations of $\mathrm{M}$ and $\mathrm{E}$ primers with selective nucleotides were screened among those previously tested in the lab because they provided the highest number of heterozygous bands in the literatures as well. E primers were end-labeled radioactively with IRD700 and IRD800. The amplified products were separated by denaturing for 6 min at $96^{\circ} \mathrm{C}$ on $6 \%$ polyacrylamide gel done at $1500 \mathrm{~V}, 60 \mathrm{~mA}$, and $15 \mathrm{~W}$ for $60-90 \mathrm{~min}$ at $55^{\circ} \mathrm{C}$ by DNA analyzer 2400 (Bioscience, USA). Amplified bands were scored as present (1) or absent (0), smeared and weak bands 
were discarded. Only reproducible bands were used to construct the original binary data matrix. Genetic similarities among accessions were evaluated by estimating the Dice and also Jaccard methods (Dice, 1945; Jaccard, 1908). The generated dendrogram (NTSYS-PC ver. 2.02 package) was compared by computing the cophenetic correlation. Genetic similarity (GS) between two cultivars i and $j$ was calculated based on Jaccard's similarity coefficient (Jaccard, 1908), GS ij = $a$ / $(n-d)$, where $a$ is the number of fragments in common between the two cultivars, $d$ is the number of fragments absent in both cultivars and $n$ is the total number of fragments scored.

\section{Flow cytometry (FCM)}

Young leaf segments (around $1-2 \mathrm{~cm}^{2}$ ) from 21 samples of the actively growing in vitro olive shoots and the same size of fresh young leaf of Parsley (Petroselinum crispum) $(2 n=2 x=22 ; 2 C$ DNA amount $=$ $4.46 \mathrm{pg}$, as an internal standard), were chopped with a razor blade in $400 \mu \mathrm{L}$ nuclei isolation buffer (Cystain UV Precise P, Partec, DE) on a plastic petri dish according to (Yokoya et al., 2000). To reduce the interaction between secondary compounds, $10 \mathrm{~g} / \mathrm{L}$ polyvinyl pyrrolidone (PVP) was added to the nuclei isolation buffer. The lysate was filtered through a $50 \mu \mathrm{m}$ Cell Trics and brought up to $2 \mathrm{~mL}$ with staining buffer (saline solution containing fetal bovine serum and sodium azide $(0.09 \%)$ as a preservative including $12 \mu \mathrm{L}$ Propidium lodide (PI) and $6 \mu \mathrm{L}$ ribonuclease (RNase)). In order to eliminate cell debris, the nuclear suspension was then filtered through a $30 \mu \mathrm{m}$ Cell Trics. After 5 min incubation period on ice, around 10,000 nuclei were analyzed by FCM (Partec, DE). Fluorescence intensity - 540 and $615 \mathrm{~nm}-$ excitation and emission respectively were measured by means of laser beam. Estimates of the ratio of fluorescence intensities of each olive to parsley sample ratio (P1/P2) were based on the means of at least 4 repetitions, giving peaks with a coefficient of variation of less than $5 \%$. The nuclear genome size of each type of plant material was estimated according to Yokoya et al., (2000).

\section{Experimental design and statistical analysis}

A flow diagram of the experimental design is illustrated in (Fig. 9). It shows the processes of sampling, formation of CIS and MIS and leaf sampling for assessment of genetic diversity. The diagram simply shows the materials and methods highlighting undesired callus formation at the base of plantlets to distinguish shoots originated from callus and those generated from meristem (normal in vitro proliferation), and necessitate the investigation of genetic stability of CIS and MIS.

The micropropagation experiments were conducted under a completely randomized design with at least 25 replications. In all proliferation experiments, growth indices including number of axillary shoots, main shoot length $(\mathrm{cm})$, number of leaves on main shoot and visual growth quality (1-5 scoring where 1 and 5 are the worst and the best qualities, respectively) were recorded after 6 weeks. The percent of callus production at the base of in vitro shoots and callus volume $\left(\mathrm{cm}^{3}\right)$ were also recorded. Data were evaluated by the analysis of variance (ANOVA) according to the general linear model (GLM) procedure 
using statistical software SAS (Institute Inc., Cary, NC, USA). Mean comparisons among treatments were conducted using LSD at the $\mathrm{P} \leq 0.01$ level of probability.

\section{Abbreviations}

AFLP, amplified fragments length polymorphism; BAP, 6-benzylaminopurine; CIS, callus-induced shoots; FCM, flow cytometry; MIS, meristem-induced shoots; MS, Murashige and Skoog; OM, olive media (ROM, Rugini olive media); PGRs, plant growth regulators; PMB, periodical mini bioreactor; PVP, polyvinyl pyrrolidone; VS, Van der salm; 2iP, 6-ץ Y-Dimethylallylaminopurine.

\section{Declarations}

\section{Ethics approval and consent to participate}

'Not applicable'

\section{Consent for publication}

'Not applicable'

\section{Availability of data and materials}

All data generated or analyzed during this study are included in this published article and its supplementary information files or the datasets used and/or analyzed during the current study are available from the corresponding author on reasonable request.

\section{Competing interests}

"The authors declare that they have no competing interests"

\section{Funding}

This study was financially supported by Agricultural Biotechnology Research Institute of Iran (ABRII) and University of Tarbiat Modares Research Core (Grant No: IG-39806).

\section{Authors' contributions}

$A Y$ and MJK conceived and designed research. LM conducted experiments. MN, AAZ, MF and DD contributed new reagents or analytical tools. LM and MF analyzed data. LM wrote the manuscript. All 


\section{Acknowledgements}

'Not applicable'

\section{References}

1. Ahn SY, Choi KO. A. Light Adaptability of Wild Evergreen Ternstroemia gymnanthera for Development of Material of Plant of Indoor Garden. Journal of Human Plant Environment Society 2016. doi: http://db.koreascholar.com/article.aspxcode=311700.

2. Ali A, Ahmad T, Abbasi NA, Hafiz IA. Effect of different media and growth regulators on in vitro shoot proliferation of olive cultivar 'moraiolo'. Pakistan Journal of Botany 2009; doi: http://www.pakbs.org//contents.html.

3. Bandelj D, Jakše J, Javornik B. Assessment of genetic variability of olive varieties by microsatellite and AFLP markers. Euphytica 2004; doi:. https://doi.org/10.1023/B:EUPH.0000019552.42066.10.

4. Bartolini G, Prevost G, Messeri C, Carignani G. Olive germplasm: cultivars and world-wide collections. FAO, Rome. (Italy). Plant Production and Protection Div1998.

5. Belaj A, Satovic Z, Cipriani G, Baldoni L, Testolin R, Rallo L, Trujillo I. Comparative study of the discriminating capacity of RAPD, AFLP and SSR markers and of their effectiveness in establishing genetic relationships in olive. Theor Appl Genet. 2003. doi:https://doi.org/10.1007/s00122-003-13015.

6. Benelli C, De Carlo A. In vitro multiplication and growth improvement of Olea europaea L. cv Canino with temporary immersion system $\left(\right.$ Plantform $^{\mathrm{TM}}$ ). 3 Biotech 2018; doi: https://doi.org/10.1007/s13205-018-1346-4.

7. Besnard G, Baali-Cherif D. Coexistence of diploids and triploids in a Saharan relict olive: Evidence from nuclear microsatellite and flow cytometry analyses. CR Biol. 2009. doi:https://doi.org/10.1016/j.crvi.2009.09.014.

8. Bradaï F, Pliego-Alfaro F, Sánchez-Romero C. Somaclonal variation in olive (Olea europaea L.) plants regenerated via somatic embryogenesis: influence of genotype and culture age on phenotypic stability. Sci Hortic. 2016. doi:https://doi.org/10.1016/j.scienta.2016.10.031.

9. Bradaï F, Sánchez-Romero C, Martín C. Somaclonal variation in olive (Olea europaea L.) plants regenerated via somatic embryogenesis: Influence of genotype and culture age on genetic stability. Sci Hortic. 2019. doi:https://doi.org/10.1016/j.scienta.2019.03.010.

10. Brito G, Lopes T, Loureiro J, Rodriguez E, Santos C. Assessment of genetic stability of two micropropagated wild olive species using flow cytometry and microsatellite markers. Trees. 2010. doi:https://doi.org/10.1007/s00468-010-0442-9. 
11. Bustan A, Avni A, Lavee S, Zipori I, Yeselson Y, Schaffer AA, Riov J, Dag A. Role of carbohydrate reserves in yield production of intensively cultivated oil olive (Olea europaea L.) trees. Tree physiology. 2011. doi:https://doi.org/10.1093/treephys/tpr036.

12. De la Rosa R, Angiolillo A, Guerrero C, Pellegrini M, Rallo L, Besnard G, Bervillé A, Martin A, Baldoni L. A first linkage map of olive (Olea europaea L.) cultivars using RAPD, AFLP, RFLP and SSR markers. Theor Appl Genet. 2003. doi:https://doi.org/10.1007/s00122-002-1189-5.

13. Dice LR. Measures of the amount of ecologic association between species. Ecology. 1945. doi:https://doi.org/10.2307/1932409.

14. Doyle JJ, Doyle JL. A rapid DNA isolation procedure for small quantities of fresh leaf tissue. Phytochemical Bulletin. 1987;19:1.

15. Flora LL, Madore MA. Stachyose and mannitol transport in olive (Olea europaea L.). Planta. 1993. doi:https://doi.org/10.1007/BF00198210.

16. Grati-Kamoun N, Mahmoud FL, Rebaï A, Gargouri A, Panaud O, Saar A. Genetic diversity of Tunisian olive tree (Olea europaea L.) cultivars assessed by AFLP markers. Genet Resour Crop Evol. 2006. doi:https://doi.org/10.1007/s10722-004-6130-0.

17. Grigoriadou K, Vasilakakis M, Tzoulis T, Eleftheriou EP. Experimental use of a novel temporary immersion system for liquid culture of olive microshoots. In "Liquid Culture Systems for in vitro Plant Propagation" Springer. 2005. doi:https://doi.org/10.1007/1-4020-3200-5-18.

18. Haddad B, Carra A, Saadi A, Haddad N, Mercati F, Gristina A, Boukhalfa S, Djillali A, Carimi F. In vitro propagation of the relict laperinne's olive (Olea europaea L. subsp. Laperrinei). Plant Biosystems-An International Journal Dealing with all Aspects of Plant Biology 2018;doi: https://doi.org/10.1080/11263504.2017.1306002.

19. Jaccard P. Nouvelles recherches sur la distribution florale. Bull Soc Vaud Sci Nat. 1908;44:223.

20. Krishna H, Alizadeh M, Singh D, Singh U, Chauhan N, Eftekhari M, Sadh RK. Somaclonal variations and their applications in horticultural crops improvement. 3 Biotech. 2016. doi:https://doi.org/10.1007/s13205-016-0389-7.

21. Läuchli A. Functions of boron in higher plants: recent advances and open questions. Plant Biol. 2002. doi:https://doi.org/10.1055/s-2002-25741.

22. Leva A, Sadeghi H, Petruccelli R. Carbohydrates modulate the in vitro growth of olive microshoots. I. The analysis of shoot growth and Branching patterns. J Plant Growth Regul. 2013. doi:https://doi.org/10.1007/s00344-012-9275-7.

23. López-Escudero FJ, Mercado-Blanco J. Verticillium wilt of olive: a case study to implement an integrated strategy to control a soil-borne pathogen. Plant soil. 2011. doi:https://doi.org/10.1007/s11104-010-0629-2.

24. Loureiro J, Rodriguez E, Costa A, Santos C. Nuclear DNA content estimations in wild olive (Olea europaea L. ssp. europaea var. sylvestris Brot.) and portuguese cultivars of $O$. europaea using flow cytometry. Genet Resour Crop Evol. 2007. doi:https://doi.org/10.1007/s10722-006-9115-3. 
25. Mirzaei L, Jafarkhani Kermani M, Yadollahi A, Naderpour M, Zeinanloo AA. Investigation of the effect of periodical mini bioreactor system on olive micropropagation. 11th Congress of Iranian Horticultural Science 2019, Urmia, Iran (in Persian).

26. Moradnezhad M, Hosseini R, Zarrabi MM, Golmohammadi FG. A New Approach for Olive (Arbequina cv.) Micropropagation: Effect of Dikegulac, Light and Carbon Source. International Journal of Horticultural Science and Technology 2017; doi: https://ijhst.ut.ac.ir/article_65937.

27. Oulbi S, Toufik I, Belkoura I. Somatic embryogenesis from cultured zygotic explants of some olive cultivars (Olea europaea L.). New Biotechnol. 2014. doi:https://doi.org/10.1016/j.nbt.2014.05.1999.

28. Owen CA, Bita EC, Banilas G, Hajjar SE, Sellianakis V, Aksoy U, Hepaksoy S, Chamoun R, Talhook SN, Metzidakis I. AFLP reveals structural details of genetic diversity within cultivated olive germplasm from the Eastern Mediterranean. Theor Appl Genet. 2005. doi:https://doi.org/10.1007/s00122-0041861-z.

29. Roshandel P, Mirniam A, Otroshi M, Ebrahimi MA. Novel Protocol for Stevia Rebaudiana (Bert.) Regeneration. Journal of Advanced Laboratory Research in Biology. 2013;4:15.

30. Rugini E. In vitro propagation of some olive (Olea europaea sativa L.) cultivars with different rootability, and medium development using analytical data from developing shoots and embryos. Sci Hortic. 1984. doi:https://doi.org/10.1016/0304-4238(84)90143-2.

31. Rugini E, Caricato G. Somatic embryogenesis and plant recovery from mature tissues of olive cultivars (Olea europaea L.) 'Canino' and 'Moraiolo'. Plant Cell Rep. 1995. doi:https://doi.org/10.1007/BF00233645.

32. Rugini E, Cristofori V, Silvestri C. Genetic improvement of olive (Olea europaea L.) by conventional and in vitro biotechnology methods. Biotechnology advances. 2016. doi:https://doi.org/10.1016/j.biotechadv.2016.03.004.

33. Rugini E, Gutierrez-Pesce P, Spampinato P, Ciarmiello A, D'Ambrosio C. New perspective for biotechnologies in olive breeding: morphogenesis, in vitro selection and gene transformation. In "III International Symposium on Olive Growing 474" 1997; doi: https://doi.org/10.17660/ActaHortic.1999.474.18.

34. Sadder MT. In vitro establishment of olive (Olea europaea L.) 'Nabali'in still liquid medium and callus culture (Research Note). Dirasat, Agricultural Sciences 2002. 29.

35. Shaul O. Magnesium transport and function in plants: the tip of the iceberg. Biometals. 2002. doi:https://doi.org/10.1023/A:1016091118585.

36. Vos P, Hogers R, Bleeker M, Reijans M, Lee Tvd, Hornes M, Friters A, Pot J, Paleman J. Kuiper, M. AFLP: a new technique for DNA fingerprinting. Nucleic acids research. 1995. doi:https://doi.org/10.1093/nar/23.21.4407.

37. Yokoya K, Roberts A, Mottley J, Lewis R, Brandham P. Nuclear DNA amounts in roses. Ann Bot. 2000. doi:https://doi.org/10.1006/anbo.1999.1102.

38. Zohary D, Hopf M. Olive. Olea europaea. Domestication of plants in the Old World. Oxford: Clarendon Press; 1994. 
Figures

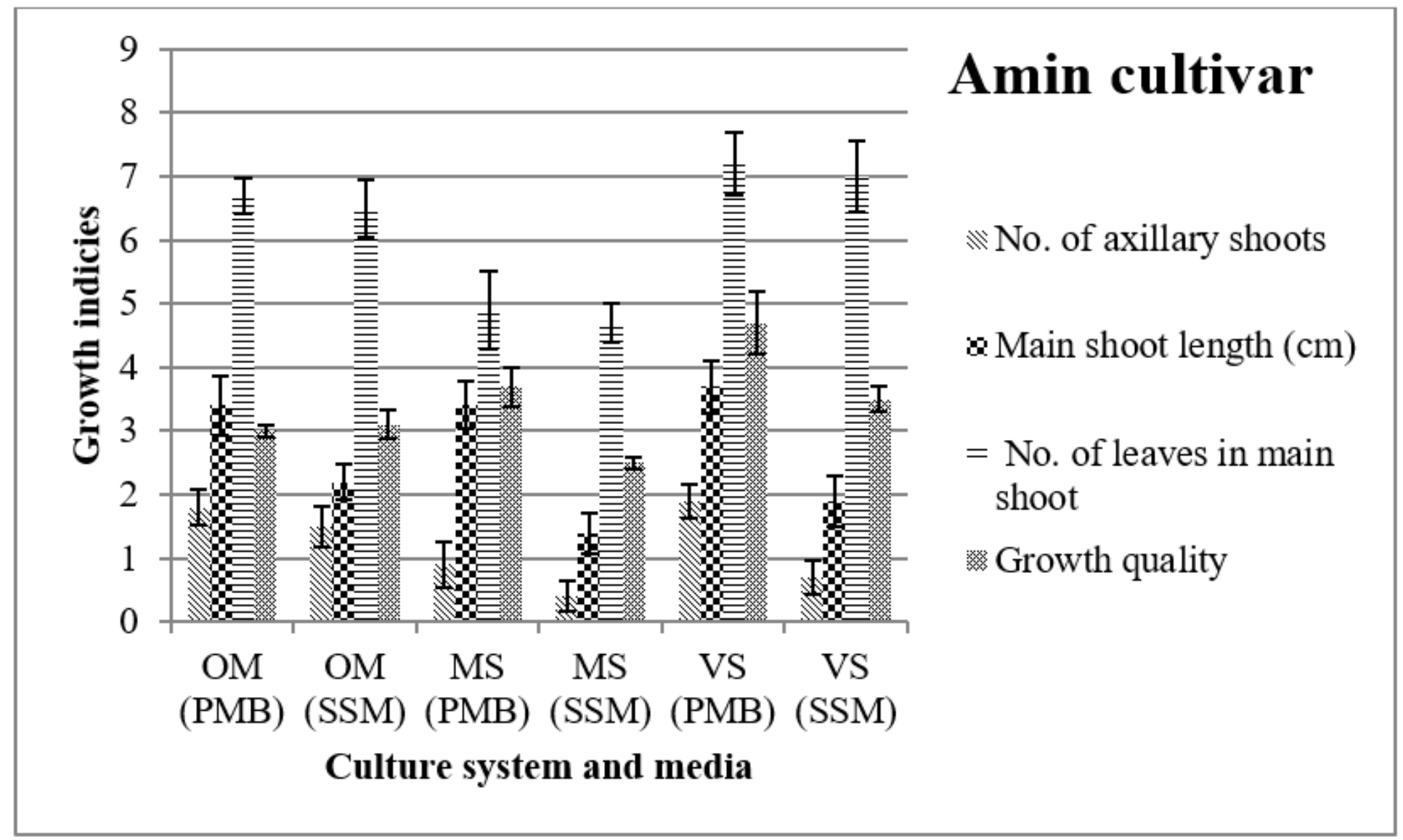

Figure 1

Interaction effects of media and culture system on olive cv $₫$ Amin $₫$ growth indices. 


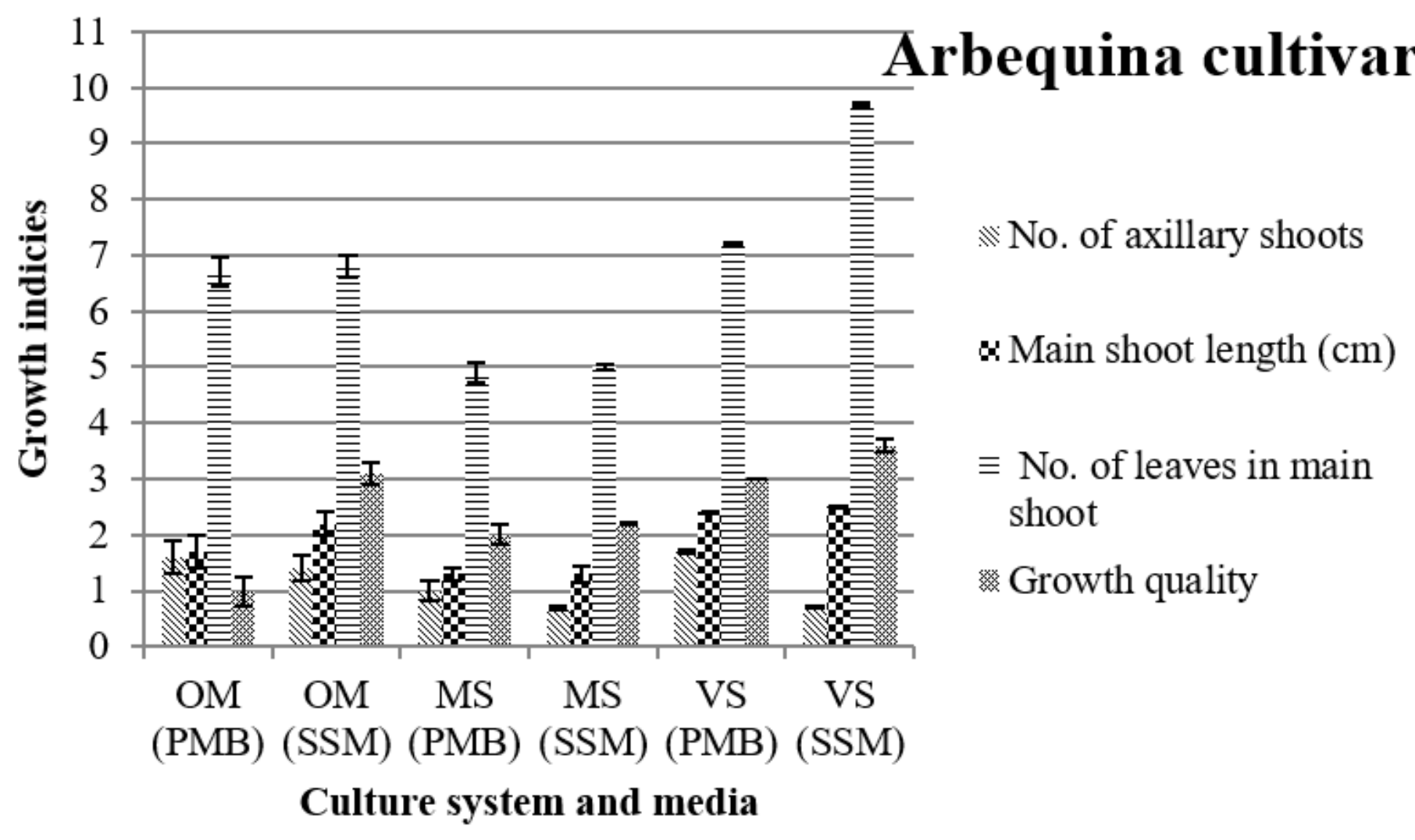

Figure 2

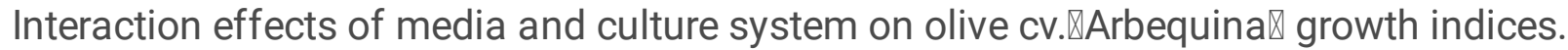




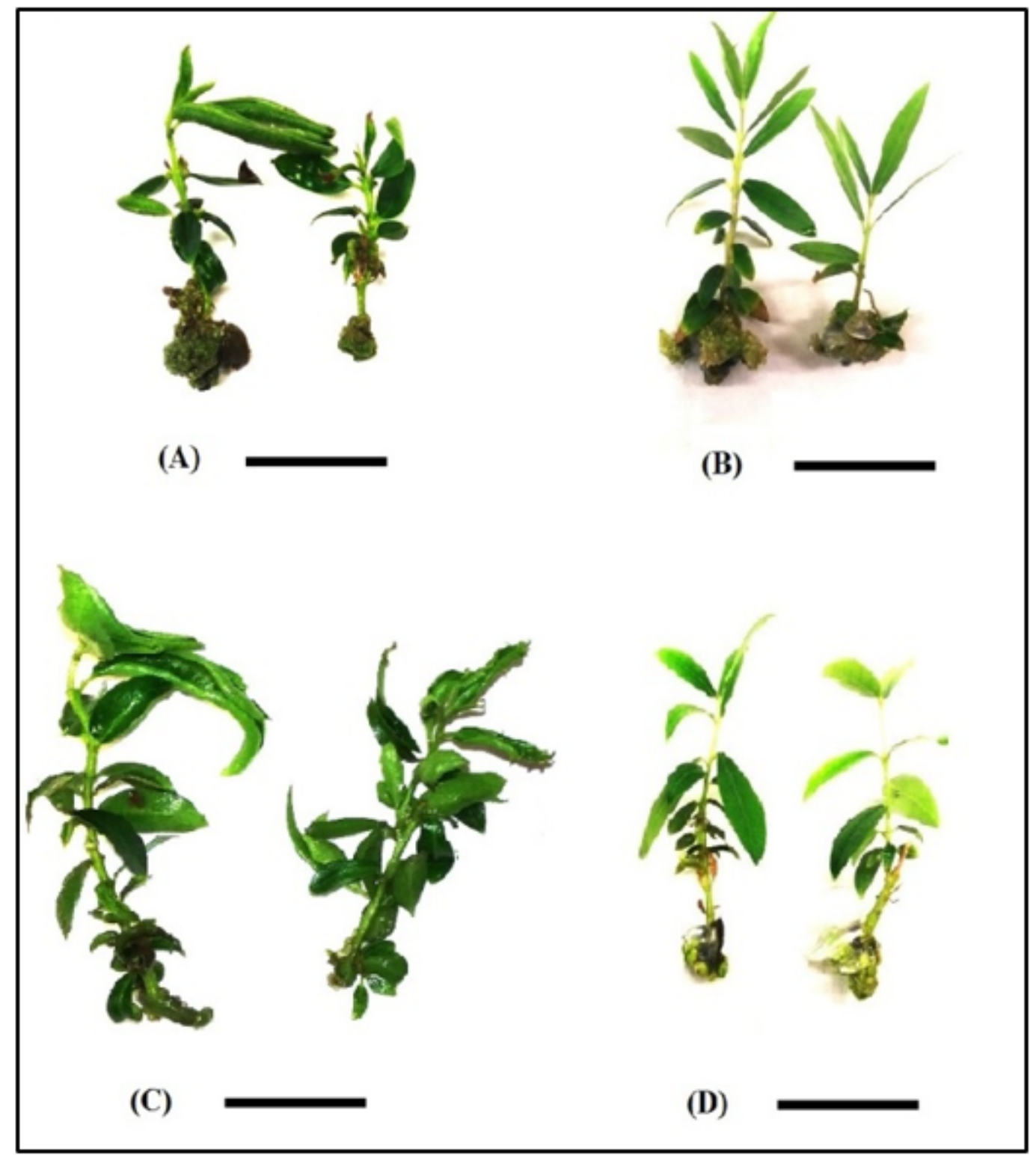

Figure 3

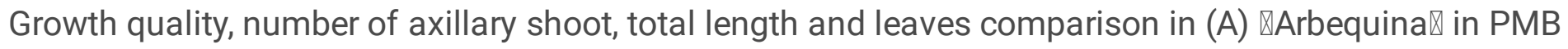

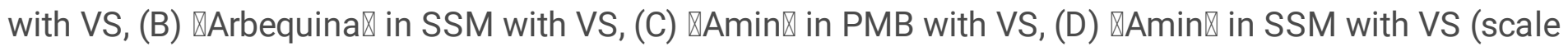
bar $1.5 \mathrm{~cm})$. 


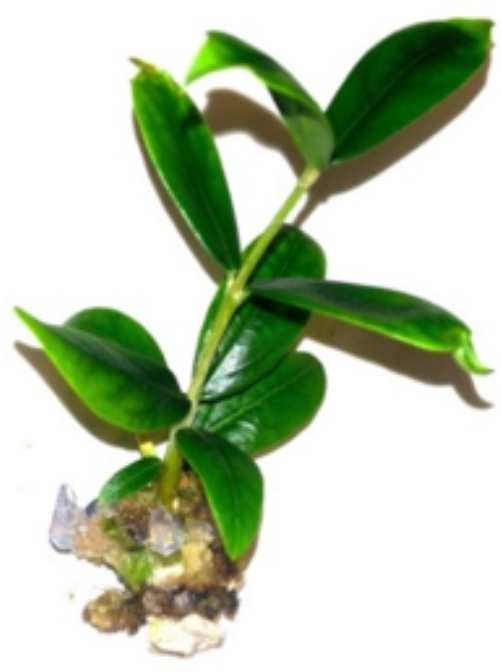

(A)

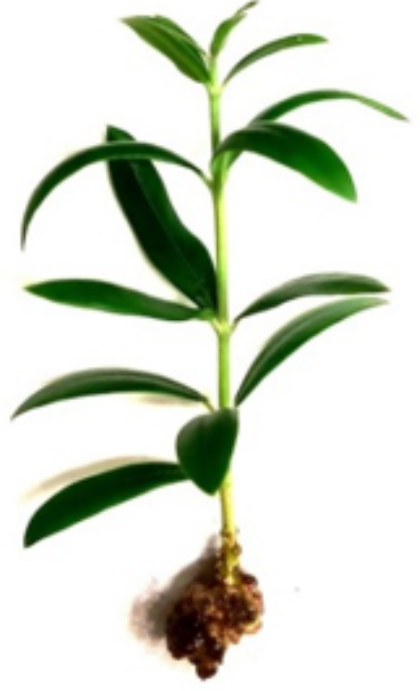

(B)

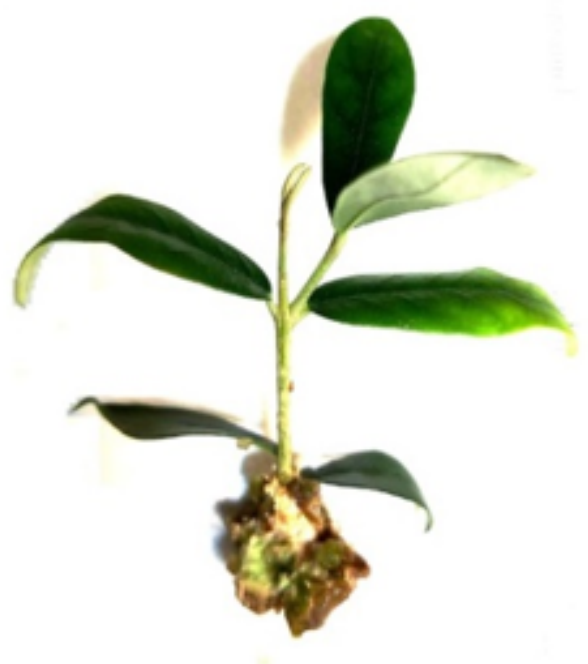

(C)

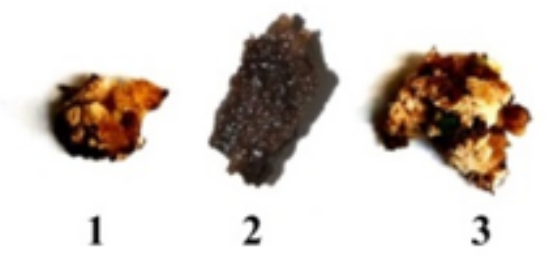

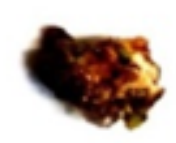

4
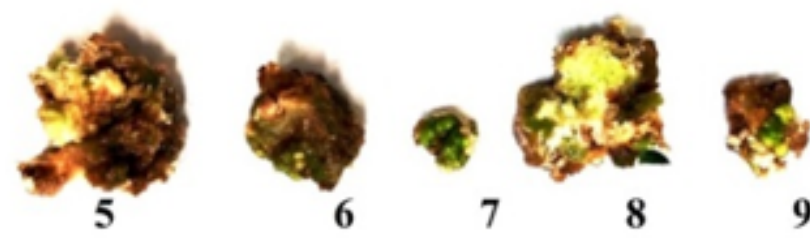

9

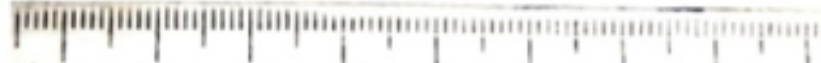
$\begin{array}{lllllll}10 & 11 & 12 & 13 & 14 & 15 & 15\end{array}$

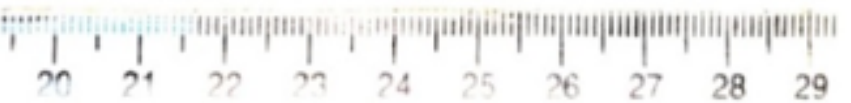

(D)

Figure 4

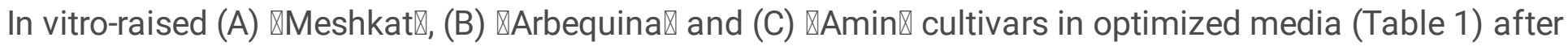

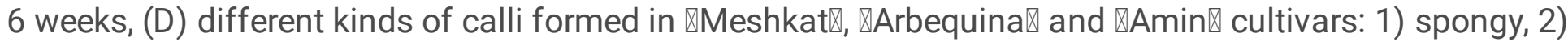
dead crystalized, 3) puffy, 4) dense vitrified, 5) spongy bicolored, 6) green solid, 7) green dense, 8) greenish spongy and 9) strict tricolored. 

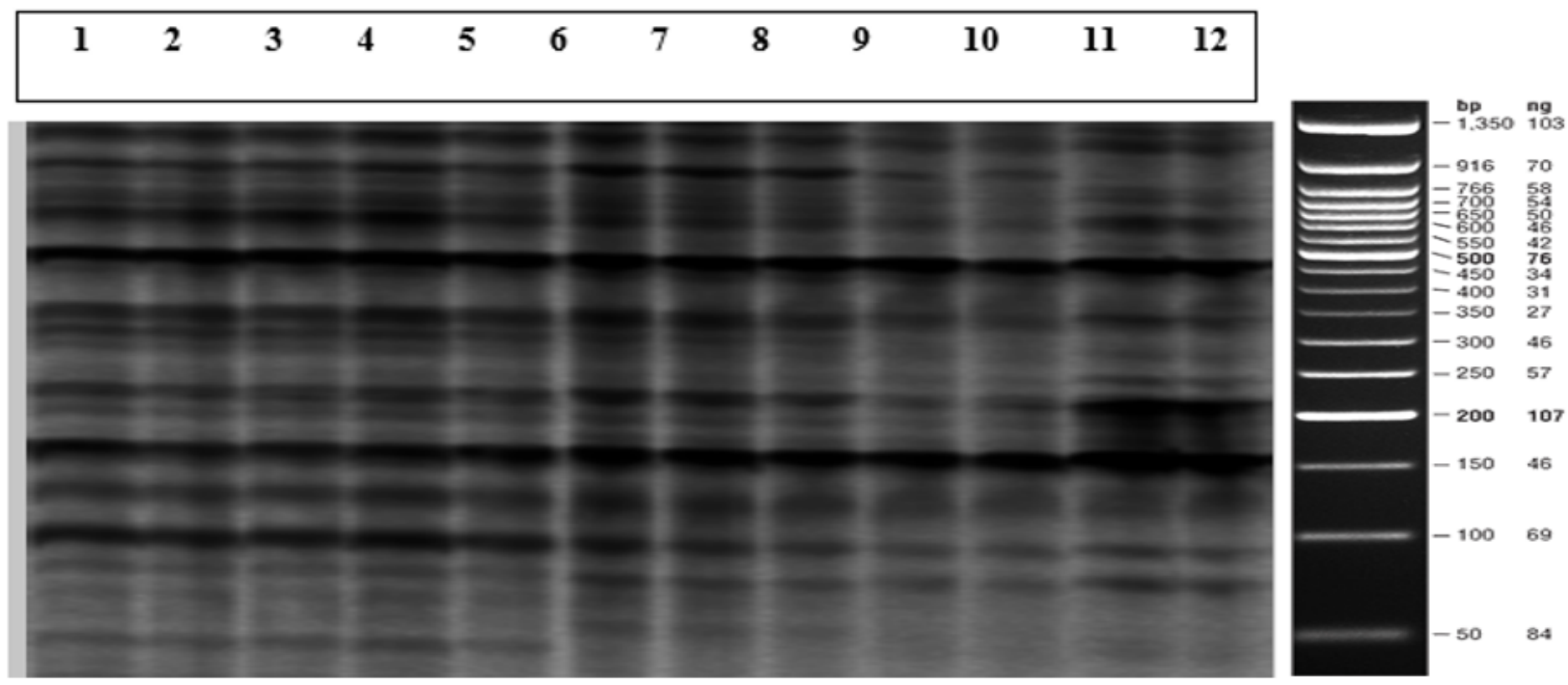

\section{Figure 5}

Highly monomorphic bands in MIS and CIS in 1) Meshkat4MIS, 2) Meshkat4CIS, 3) Meshkat2CIS, 4) Meshkat1MIS, 5) Arbequina2MIS, 6) Arbequina2CIS, 7) Arbequina3MIS, 8) Arbequina3CIS, 9) Amin3MIS, 10) Amin3CIS, 11) Amin4MIS and 12) Amin1CIS in application of EAGG and MGC primer pair (50 bp ladder, Fermentas, USA).

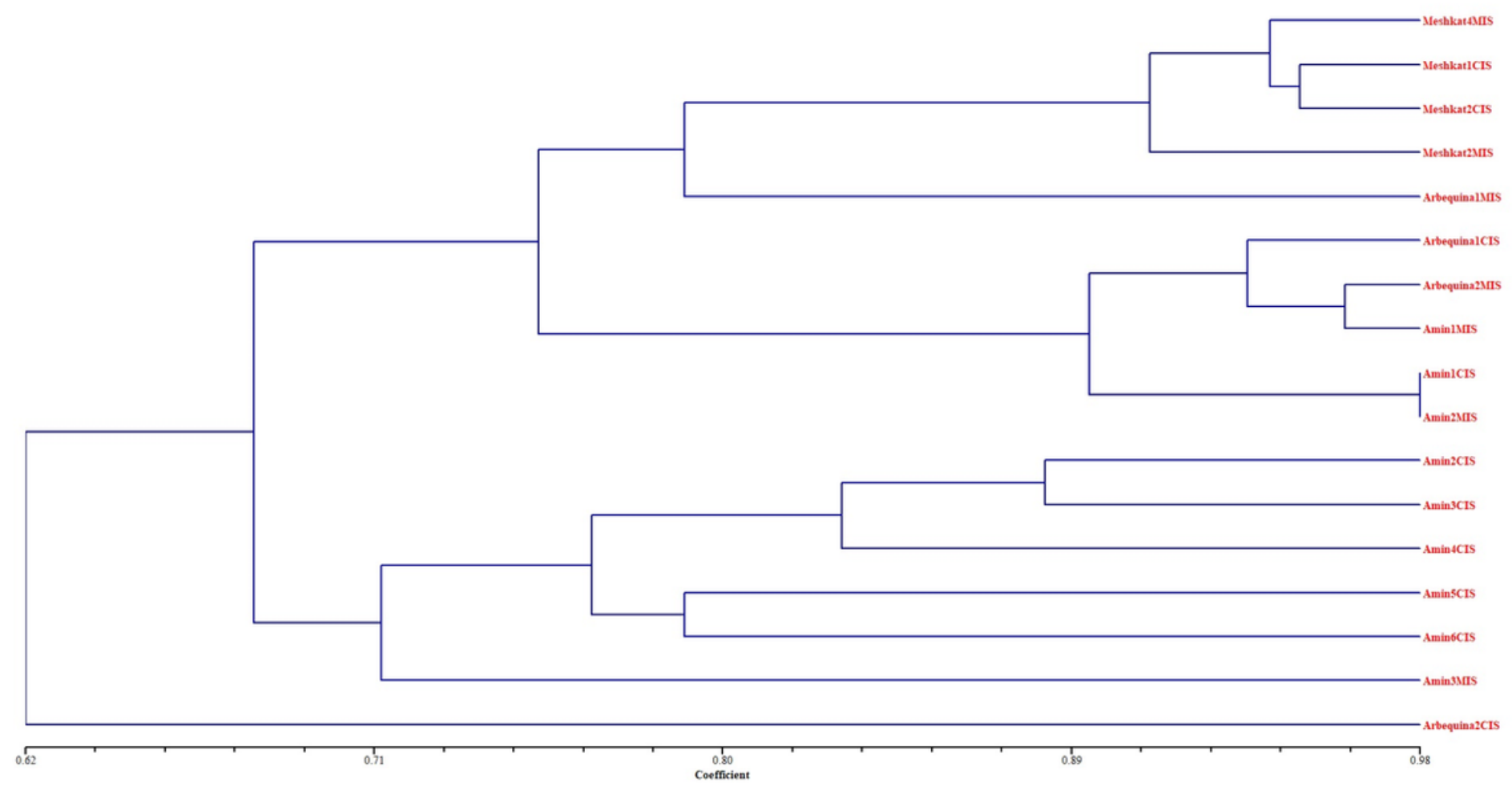

Figure 6 
Dendrogram (NTSYS-PC ver. 2.02 package) of three cultivars with MIS and CIS.

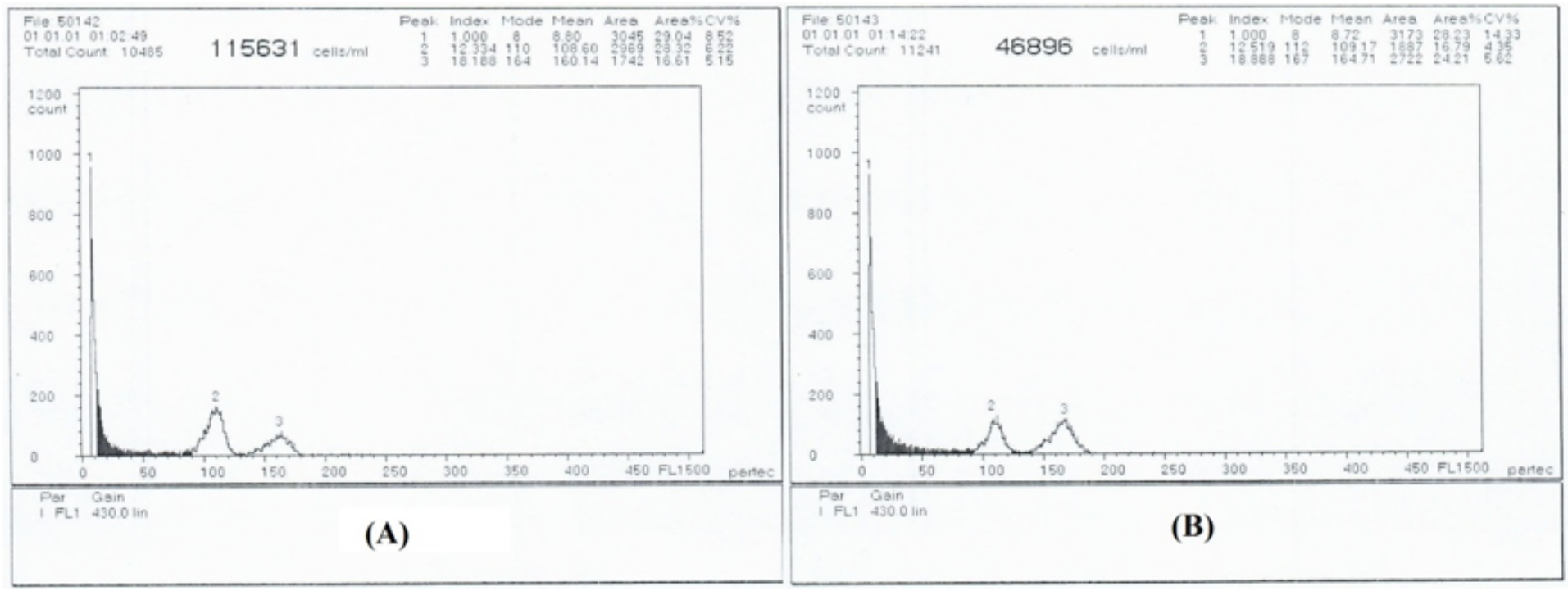

Figure 7

Typical histograms of $₫$ Meshkat $\llbracket$ cultivar for (A) CIS and (B) MIS with more than 10,000 nuclei analyzed with 4 repetitions.
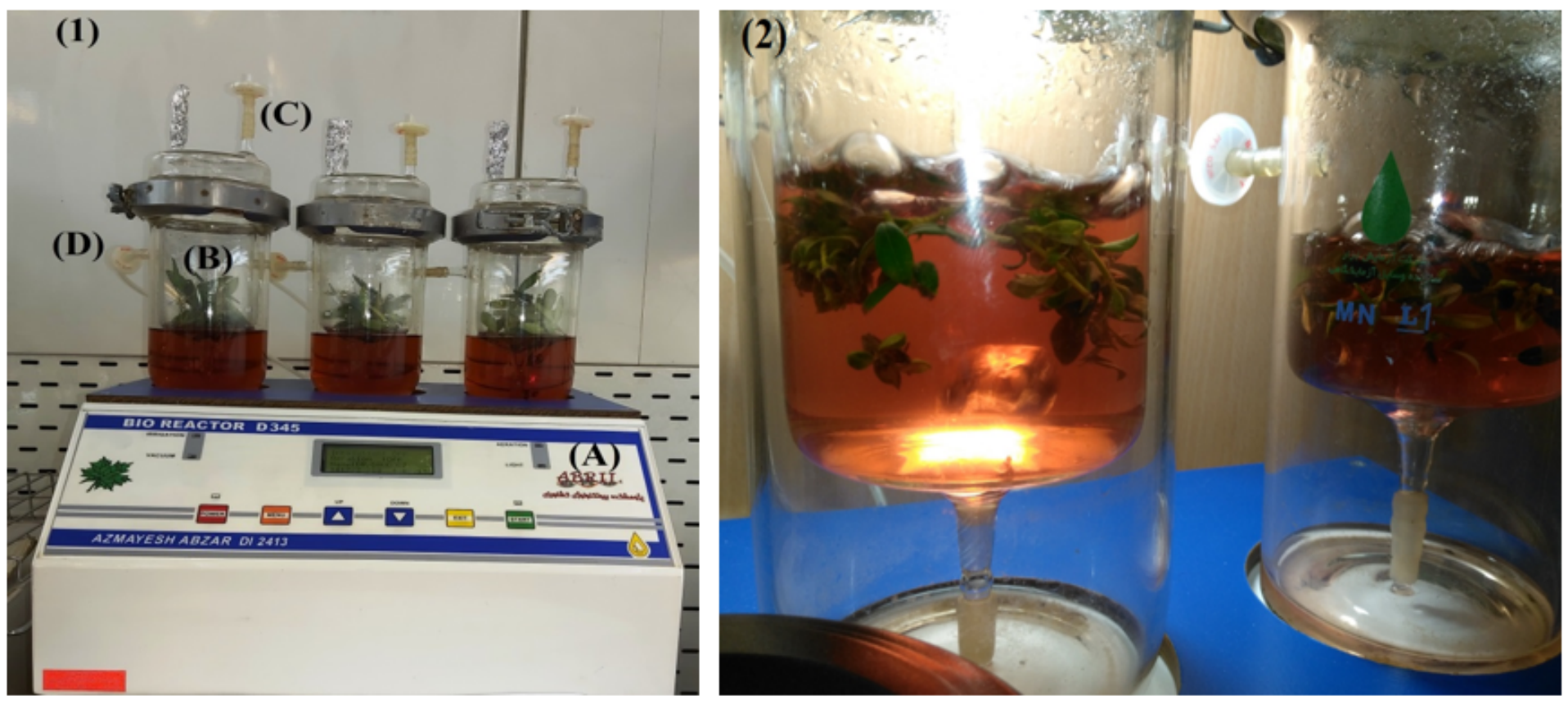

\section{Figure 8}

Periodical mini bioreactor (PMB) system: (1) compelete equipment including (A) controller, (B) jars with two glass layers which inner layer contained the plant material and outer layer contained the culture medium, (C) and (D) $0.2 \mu \mathrm{m}$ cellulose nitrate filters for entrance of sterilized air to appliance (where (C) was for vacuuming air, and (D) was for importing air and vice versa) (2) Immersion step. 

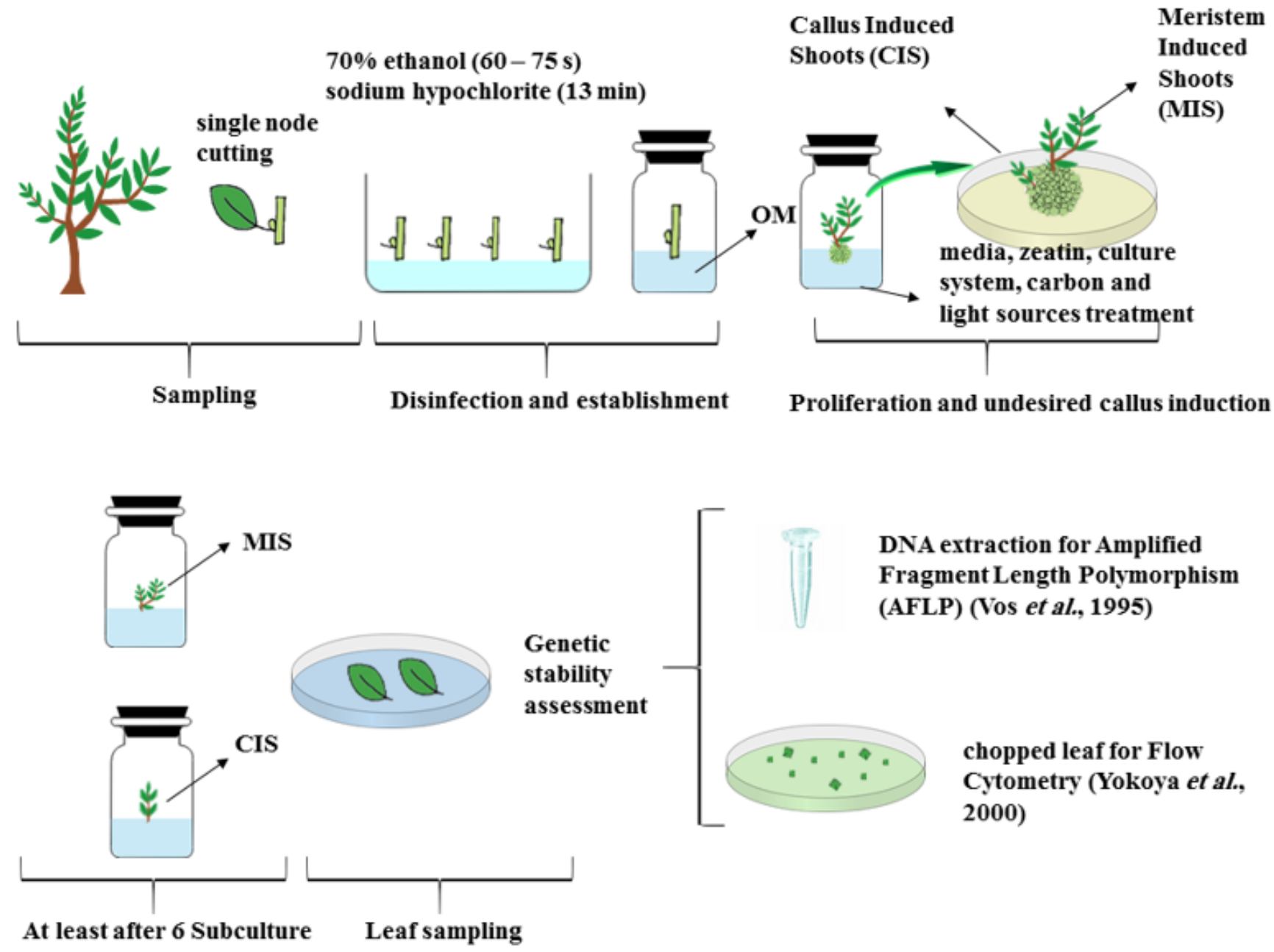

Figure 9

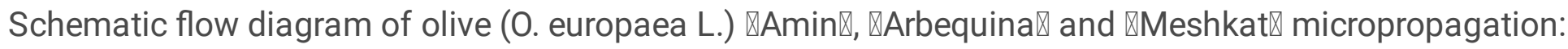
Well-grown single node cuttings were surface-sterilized and established in modified OM (OM supplemented with $4 \mathrm{mg} / \mathrm{L}$ zeatin plus $0.5 \mathrm{mg} / \mathrm{L} 2 \mathrm{ip}$ ). During proliferation stage, regarding the media with unintentionally callus formation (high zeatin media, mannitol enriched media and lower light intensity condition), CIS and MIS were proliferated separately. In vitro plantlets were sub-cultured for at least 126 days. Then leaf materials were tested for genetic stability assessment by amplified fragments length polymorphism (AFLP) and flow cytometry (FCM). 